Atmos. Chem. Phys., 18, 12241-12256, 2018

https://doi.org/10.5194/acp-18-12241-2018

(C) Author(s) 2018. This work is distributed under

the Creative Commons Attribution 4.0 License.

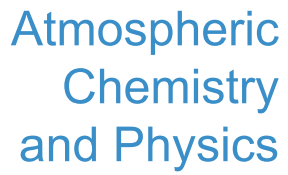

(c) (P)

\title{
Effectiveness of ammonia reduction on control of fine particle nitrate
}

\author{
Hongyu Guo ${ }^{1}$, Rene Otjes ${ }^{2}$, Patrick Schlag ${ }^{3,4, a}$, Astrid Kiendler-Scharr ${ }^{4}$, Athanasios Nenes ${ }^{1,5,6,7}$, and \\ Rodney J. Weber ${ }^{1}$ \\ ${ }^{1}$ School of Earth and Atmospheric Sciences, Georgia Institute of Technology, Atlanta, GA 30332, USA \\ ${ }^{2}$ Energy Research Centre of the Netherlands (ECN), Petten, the Netherlands \\ ${ }^{3}$ Institute for Marine and Atmospheric Research Utrecht (IMAU), Utrecht University, Utrecht, the Netherlands \\ ${ }^{4}$ Institute for Energy and Climate Research (IEK-8) - Troposphere, Forschungszentrum Jülich, Jülich, Germany \\ ${ }^{5}$ School of Chemical and Biomolecular Engineering, Georgia Institute of Technology, \\ Atlanta, GA 30332, USA \\ ${ }^{6}$ Institute for Chemical Engineering Sciences, Foundation for Research and Technology - \\ Hellas, Patras, 26504, Greece \\ ${ }^{7}$ Institute for Environmental Research and Sustainable Development, National Observatory of Athens, \\ Palea Penteli, Athens, 15236, Greece \\ ${ }^{a}$ now at: Institute of Physics, University of Sao Paulo, Sao Paulo, SP, Brazil
}

Correspondence: Rodney J. Weber (rweber@eas.gatech.edu)

Received: 11 April 2018 - Discussion started: 8 May 2018

Revised: 2 August 2018 - Accepted: 7 August 2018 - Published: 24 August 2018

\begin{abstract}
In some regions, reducing aerosol ammonium nitrate $\left(\mathrm{NH}_{4} \mathrm{NO}_{3}\right)$ concentrations may substantially improve air quality. This can be accomplished by reductions in precursor emissions, such as nitrogen oxides $\left(\mathrm{NO}_{x}\right)$ to lower nitric acid $\left(\mathrm{HNO}_{3}\right)$ that partitions to the aerosol, or reductions in ammonia $\left(\mathrm{NH}_{3}\right)$ to lower particle $\mathrm{pH}$ and keep $\mathrm{HNO}_{3}$ in the gas phase. Using the ISORROPIA-II thermodynamic aerosol model and detailed observational data sets, we explore the sensitivity of aerosol $\mathrm{NH}_{4} \mathrm{NO}_{3}$ to gas-phase $\mathrm{NH}_{3}$ and $\mathrm{NO}_{x}$ controls for a number of contrasting locations, including Europe, the United States, and China. $\mathrm{NO}_{x}$ control is always effective, whereas the aerosol response to $\mathrm{NH}_{3}$ control is highly nonlinear and only becomes effective at a thermodynamic sweet spot. The analysis provides a conceptual framework and fundamental evaluation on the relative value of $\mathrm{NO}_{x}$ versus $\mathrm{NH}_{3}$ control and demonstrates the relevance of $\mathrm{pH}$ as an air quality parameter. We find that, regardless of the locations examined, it is only when ambient particle $\mathrm{pH}$ drops below an approximate critical value of 3 (slightly higher in warm and slightly lower in cold seasons) that $\mathrm{NH}_{3}$ reduction leads to an effective response in $\mathrm{PM}_{2.5}$ mass. The required amount of $\mathrm{NH}_{3}$ reduction to reach the
\end{abstract}

critical $\mathrm{pH}$ and efficiently decrease $\mathrm{NH}_{4} \mathrm{NO}_{3}$ at different sites is assessed. Owing to the linkage between $\mathrm{NH}_{3}$ emissions and agricultural productivity, the substantial $\mathrm{NH}_{3}$ reduction required in some locations may not be feasible. Finally, controlling $\mathrm{NH}_{3}$ emissions to increase aerosol acidity and evaporate $\mathrm{NH}_{4} \mathrm{NO}_{3}$ will have other effects, beyond reduction of $\mathrm{PM}_{2.5} \mathrm{NH}_{4} \mathrm{NO}_{3}$, such as increasing aerosol toxicity and potentially altering the deposition patterns of nitrogen and trace nutrients.

\section{Introduction}

Global trends of increasing gas-phase ammonia $\left(\mathrm{NH}_{3}\right)$ concentrations (Erisman et al., 2008) have multiple environmental implications. As part of the global nitrogen cycle (Fowler et al., 2013), excessive $\mathrm{NH}_{3}$ deposition promotes alga blooms, degrades water quality, and may be toxic for ecosystems (Krupa, 2003; Camargo and Alonso, 2006). $\mathrm{NH}_{3}$ is one of the most important atmospheric alkaline species, as it influences the $\mathrm{pH}$ of clouds, fogs, precipitation (Wells et al., 1998), and fine particles ( $\left.\mathrm{PM}_{2.5}\right)$ (Guo et al., 2017c). 
Agricultural practices, including use of synthetic nitrogenbased fertilizer and domesticated animal manure, are the major anthropogenic $\mathrm{NH}_{3}$ sources (Galloway et al., 2003; Aneja et al., 2009; Zhang et al., 2018). Minor contributions include biomass burning (e.g., forest fires), fossil fuel combustion, and vehicle catalytic converters (Perrino et al., 2002; Behera et al., 2013). Higher temperatures resulting from global warming can also potentially enhance $\mathrm{NH}_{3}$ emissions (Skjøth and Geels, 2013). Given that fertilizer usage supports food production for about half the global population (Erisman et al., 2008), $\mathrm{NH}_{3}$ emissions are linked to world population and so expected to increase into the 21st century (Gerland et al., 2014). Compared to the limited regulation of $\mathrm{NH}_{3}$ emissions, other anthropogenic air pollutants that are linked to acidic atmospheric species, such as sulfur dioxide $\left(\mathrm{SO}_{2}\right)$ and nitrogen oxide $\left(\mathrm{NO}_{x}\right)$, are regulated through air quality standards, which accounts for their observed decreasing gas and aerosol concentrations in the United States (Hand et al., 2012; Russell et al., 2012; Hidy et al., 2014), western Europe, and China (Warner et al., 2017). Decreasing trends of $\mathrm{SO}_{2}$ and $\mathrm{NO}_{x}$ emissions are expected to continue on global scales throughout the century (IPCC, 2013). The contrast between increasing $\mathrm{NH}_{3}$ and decreasing $\mathrm{SO}_{2}$ and $\mathrm{NO}_{x}$ leads to changes in aerosol composition and mass concentration. $\mathrm{NH}_{3}$ reacts rapidly with the oxidized products of $\mathrm{SO}_{2}$ and $\mathrm{NO}_{x}$, sulfuric $\left(\mathrm{H}_{2} \mathrm{SO}_{4}\right)$ and nitric $\left(\mathrm{HNO}_{3}\right)$ acids, to form ammonium sulfate $\left(\left(\mathrm{NH}_{4}\right)_{2} \mathrm{SO}_{4}\right.$, or other forms such as $\left.\mathrm{NH}_{4} \mathrm{HSO}_{4},\left(\mathrm{NH}_{4}\right)_{3} \mathrm{H}\left(\mathrm{SO}_{4}\right)_{2}\right)$, and ammonium nitrate $\left(\mathrm{NH}_{4} \mathrm{NO}_{3}\right)$ aerosols, which globally constitute an important fraction of ambient $\mathrm{PM}_{2.5}$ mass (Kanakidou et al., 2005; Sardar et al., 2005; Zhang et al., 2007). These reaction pathways link $\mathrm{NH}_{3}$ to $\mathrm{PM}_{2.5}$ mass and its subsequent impacts on human health (Pope et al., 2004; Lim et al., 2012; Lelieveld et al., 2015; Cohen et al., 2017) and the climate system (Haywood and Boucher, 2000; Bellouin et al., 2011; IPCC, 2013).

A number of studies using regional- or global-scale models have investigated $\mathrm{NH}_{3}$ controls as a way to reduce $\mathrm{PM}_{2.5}$ mass to meet air quality standards (Erisman and Schaap, 2004; Pinder et al., 2007, 2008; Paulot and Jacob, 2014; Bauer et al., 2016; Pozzer et al., 2017). The fundamental premise is that reducing $\mathrm{NH}_{3}$ will increase aerosol acidity (i.e., lower aerosol $\mathrm{pH}$ ) and prevent the formation of $\mathrm{NH}_{4} \mathrm{NO}_{3}$, reducing overall $\mathrm{PM}_{2.5}$ mass. As a secondary effect, lower $\mathrm{pH}$ can also reduce the sulfate production rate, such as the in-cloud $\mathrm{SO}_{2}$ oxidation by $\mathrm{O}_{3}$ (Wang et al., 2011; Cheng et al., 2016; Paulot et al., 2017). Use of largescale models to assess effectiveness of $\mathrm{NH}_{3}$ controls requires (i) good predictions of a range of pertinent emissions and sinks $\left(\mathrm{NH}_{3} ; \mathrm{NO}_{x} ; \mathrm{SO}_{2}\right.$; and nonvolatile cations, NVCs) and (ii) accurate representation of their applicable atmospheric chemical processes. Thermodynamic modules in different levels of complexity are then applied to determine sensitivities to the precursors (e.g., $\mathrm{NH}_{3}, \mathrm{HNO}_{3}$ ). In some cases (Pozzer et al., 2017), the aerosol pH is explicitly determined with an embedded thermodynamic model, such as ISORROPIA-II (Fountoukis and Nenes, 2007). Due to the complexities from all these factors, chemical-transportmodel-predicted responses to changing emissions may not align with observations. For example, the sensitivity of $\mathrm{PM}_{2.5}$ $\mathrm{pH}$ in the Community Multiscale Air Quality Modeling System (CMAQ) simulations to the mass of crustal material apportioned to the $\mathrm{PM}_{2.5}$ size range can have important effects on anticipated responses to these changing emission trends. Vasilakos et al. (2018) have shown that including too much crustal material in $\mathrm{PM}_{2.5}$ results in a predicted increasing trend in both aerosol $\mathrm{pH}$ and concentrations of $\mathrm{NH}_{4} \mathrm{NO}_{3}$, which is counter to observations (Weber et al., 2016).

Overall, calculating aerosol $\mathrm{pH}$ is a more accurate approach that provides a fundamental understanding of the factors controlling $\mathrm{HNO}_{3}-\mathrm{NO}_{3}^{-}$partitioning and therefore enables a direct evaluation of different studies. Furthermore, it is also useful to determine aerosol $\mathrm{pH}$ since it has broad application to many other important aerosol processes. For instance, $\mathrm{pH}$ is a mediator of many heterogeneous chemical processes, including various acid-catalyzed reactions (Jang et al., 2002; Eddingsaas et al., 2010; Surratt et al., 2010); gas-particle partitioning of species other than $\mathrm{HNO}_{3}$ and $\mathrm{NH}_{3}$, such as organic acids and halogens (Fridlind and Jacobson, 2000; Young et al., 2013; Guo et al., 2017a; Nah et al., 2018); and solubility of metals and other nutrient species (Meskhidze et al., 2003; Nenes et al., 2011; Longo et al., 2016; Stockdale et al., 2016; Fang et al., 2017).

In this study, we apply a more direct approach, where measured gas and particle concentrations and the thermodynamic model ISORROPIA-II are used directly in a sensitivity analysis to evaluate the effectiveness of $\mathrm{NH}_{3}$ emission controls on fine particle mass relative to $\mathrm{NO}_{x}$ control. Contrasts are made between sites that have a wide range in $\mathrm{NH}_{3}$ concentrations and aerosol composition, with a focus on a 1-year data set collected in Cabauw, the Netherlands (Schlag et al., 2016). This site had year-round high $\mathrm{NH}_{3}$ concentrations (average $7.3 \pm 6.0 \mu \mathrm{g} \mathrm{m}^{-3}, \sim 10 \mathrm{ppbv}$ ), with nitrate comprising a significant fraction of the fine particle mass $\left(30 \% \mathrm{NO}_{3}^{-}\right.$ of $\mathrm{PM}_{1}$ ), and there was a strong seasonal temperature variation. The goal is to establish a transparent and fundamental understanding on when $\mathrm{NH}_{3}$ emission controls could be an effective way to alter aerosol $\mathrm{pH}$ to reduce ammonium nitrate aerosol concentrations, without the use of a full chemical transport model.

\section{Methods}

\subsection{Sampling sites}

Cabauw. One year (July 2012 to June 2013) of online aerosol and gas measurements of inorganic species were performed at the Cabauw Experimental Site for Atmospheric Research (CESAR; $\left.51.970^{\circ} \mathrm{N}, 4.926^{\circ} \mathrm{E}\right)$, near the village 
of Cabauw, the Netherlands. Cabauw is a rural site situated approximately $45 \mathrm{~km}$ from the Atlantic Ocean and surrounded by agricultural land. Northwestern Europe has fairly high $\mathrm{NH}_{3}$ concentrations with yearly averages ranging from 1 to $14 \mu \mathrm{g} \mathrm{m}^{-3}$ (median as $4.2 \mu \mathrm{g} \mathrm{m}^{-3}$ ) for the Netherlands in 2013, reported by the Measuring Ammonia in Nature (MAN) network (Lolkema et al., 2015). Satellite-derived 14year average for western Europe is $3 \mathrm{ppbv}\left(\sim 2.3 \mu \mathrm{g} \mathrm{m}^{-3}\right)$ (Warner et al., 2017). Cabauw was somewhat higher due to intensive agriculture in the region with observed yearly $\mathrm{NH}_{3}$ average of $7.3 \pm 6.0 \mu \mathrm{g} \mathrm{m}^{-3}$ ( $\left.\sim 10 \mathrm{ppbv}\right)$. Site details, instrumentation, and measurement intercomparisons can be found in Schlag et al. (2016). The data used in this analysis are from a monitor for aerosols and gases (MARGA, Applikon Analytical BV) that was operated by the Energy Research Centre of the Netherlands (ECN). The instrument performs online measurements of soluble inorganic gases collected in a continuously wetted-wall denuder, followed by a steam-condensation system for collection of particles. Both the aqueous samples of gases and particles are measured via ion chromatography (Schaap et al., 2011; Rumsey et al., 2014), including $\mathrm{NH}_{3}, \mathrm{HNO}_{3}$, and $\mathrm{HCl}$, and particle-phase $\mathrm{NO}_{3}^{-}, \mathrm{SO}_{4}^{2-}, \mathrm{Cl}^{-}, \mathrm{NH}_{4}^{+}, \mathrm{Na}^{+}, \mathrm{K}^{+}, \mathrm{Ca}^{2+}$, and $\mathrm{Mg}^{2+}$ alternatively between $\mathrm{PM}_{1}$ and $\mathrm{PM}_{2.5}$, with each size sampled hourly (i.e., a $2 \mathrm{~h}$ interval for one size and a $1 \mathrm{~h}$ interval for gas). Measurement uncertainties were below $10 \%$ (Schaap et al., 2011). The detection limits were $0.05,0.10,0.08$, and $0.01 \mu \mathrm{g} \mathrm{m}^{-3}$ for aerosol ions $\mathrm{NH}_{4}^{+}, \mathrm{NO}_{3}^{-}, \mathrm{SO}_{4}^{2-}$, and $\mathrm{Cl}^{-}$, respectively, and 0.10 and $0.05 \mu \mathrm{g} \mathrm{m}^{-3}$ for the gases $\mathrm{HNO}_{3}$ and $\mathrm{NH}_{3}$ (Rumsey et al., 2014). Relative humidity (RH) and temperature $(T)$ data were collected at the $2 \mathrm{~m}$ level from the CESAR tower and used to represent ground level meteorological conditions (for an overview see Fig. S7 in Schlag et al., 2016).

Other sites. In addition to the Cabauw site, we analyze the effectiveness of $\mathrm{NH}_{3}$ reduction for a number of contrasting sites where we have already reported on aerosol $\mathrm{pH}$ in detail. This includes data from the Southern Oxidant and Aerosol Study (SOAS) (Guo et al., 2015); Wintertime Investigation of Transport, Emissions, and Reactivity (WINTER) (Guo et al., 2016); and California Research at the Nexus of Air Quality and Climate Change (CalNex) study (Guo et al., 2017a). Briefly, the SOAS data were collected at the Southeastern Aerosol Research and Characterization (SEARCH) Centreville ground site, representative of the southeastern US background conditions, from June to July 2013. The WINTER data were sampled from the National Center for Atmospheric Research (NCAR) C-130 aircraft operating from Feb to March 2015 mainly in the northeastern US. The CalNex data were collected from May to June 2010 in Pasadena, California, an urban site that is part of the greater Los Angeles region. As a further contrast for regions of very high $\mathrm{NH}_{3}$ concentrations, we include an analysis from published data in Beijing during winter haze events in 2015 (Wang et al., 2016), for which pH has also been investigated (Guo et al., 2017c). Table S1 in the Supplement summarizes the conditions at the various sites.

\subsection{Thermodynamic modeling}

The ISORROPIA-II thermodynamic model (Fountoukis and Nenes, 2007) was used to determine the composition and phase state of an $\mathrm{NH}_{4}^{+}, \mathrm{SO}_{4}^{2-}, \mathrm{NO}_{3}^{-}, \mathrm{Cl}^{-}, \mathrm{Na}^{+}, \mathrm{Ca}^{2+}$, $\mathrm{K}^{+}, \mathrm{Mg}^{2+}$, and water inorganic aerosol and its partitioning with corresponding gases. Thermodynamic equilibrium is assumed between fine particles and gases for all semivolatile inorganic species, including particle water and water vapor. Timescales for submicron particles to reach equilibrium are about 30 min (Dassios and Pandis, 1999; Cruz et al., 2000; Fountoukis et al., 2009). The model is run in "forward mode" to calculate gas-particle equilibrium concentrations based on the input of total concentration of inorganic species (e.g., $\mathrm{NH}_{3}+\mathrm{NH}_{4}^{+}, \mathrm{HNO}_{3}+\mathrm{NO}_{3}^{-}, \mathrm{SO}_{4}^{2-}$, and $\mathrm{Na}^{+}$). $\mathrm{SO}_{4}^{2-}$ has no gas pair as it is virtually nonvolatile in the observed temperature ranges of this study (An et al., 2007). The forward mode gives more accurate and robust results than the reverse mode since it is much less sensitive to measurement uncertainties (Hennigan et al., 2015). Inorganic ions are also assumed to be only in the aqueous phase (i.e., no solid precipitates). This entails a number of assumptions. First, the ambient RH and the history of the particles' exposure to RH result in a deliquesced particle. In many cases, diurnal swings in RH (i.e., the maximum RH in early morning) are generally sufficient to reach the deliquescent point. Furthermore, efflorescence RHs are generally low and rarely reached by the ambient RH (10 to $30 \%$ ) (Bertram et al., 2011). Thus, a deliquesced particle is often a good assumption when average ambient RH is above $50 \%$. For Cabauw, the 1 -year mean RH was $81 \pm 15 \%$ $( \pm \mathrm{SD}$ ), with RH reaching up to $90 \%$ during diurnal cycles (see Fig. S1a in the Supplement), making the presence of a liquid phase a reasonable assumption. For the other sites studied, average RHs were all above $55 \%$ (Table S1). A second assumption is that most ions are in an aqueous liquid inorganic phase and only minor fractions reside dissolved in a separate liquid organic phase, if it exists. This is supported by very good agreement between observed ammonia gas-particle partitioning with thermodynamic model predictions that do not consider an organic phase. (See Figs. S3 and S4 for this study; similar results are found in other studies, e.g., Guo et al., 2015, 2017a; and Nah et al., 2018.) Pye et al. (2018) found only minor differences in the predicted ammonia partition when an organic phase was considered. It is also assumed that the particles were internally mixed and that $\mathrm{pH}$ did not vary with size. Mixing state of the nonvolatile cations can affect particle composition and $\mathrm{pH}$ (Zhu et al., 2016), but the effect on predicted fine particle $\mathrm{pH}$ is small if a minor fraction of nonvolatile sulfate is internally mixed with the nonvolatile cations (Guo et al., 2017b); however, it can add uncertainty to predicted nitric acid partitioning (discussed below in Sect. 2.3). Since there are no data on the 
mixing state and the mass concentrations (or mole fractions) of nonvolatile cations are generally small (discussed below in Sect. 3.2 and also see Table S1), internal mixing is assumed in the following analysis.

With increasing $\mathrm{pH}$ (e.g., above 2 for oxalate), organic acids can be found at increasing quantities in the particle phase (Nah et al., 2018). However, organic acids are not considered in the ISORROPIA-II $\mathrm{pH}$ calculations. In Cabauw, it has been reported that excess $\mathrm{NH}_{4}^{+}$(i.e., $\mathrm{NH}_{4}^{+}$not paired with $\mathrm{SO}_{4}^{2-}, \mathrm{NO}_{3}^{-}$, and $\mathrm{Cl}^{-}$) was correlated with (di)carboxylic organic acids. Excess $\mathrm{NH}_{4}^{+}$on average constituted only $5 \%$ of the $\mathrm{NH}_{4}^{+}$reported by an aerosol mass spectrometer (AMS), so it is likely to have a small effect on predicted pH (Schlag et al., 2017). This is confirmed by the good agreement between measured and ISORROPIA-II-predicted $\mathrm{NH}_{3}-\mathrm{NH}_{4}^{+}$partitioning without considering organic acids or other organic species (see Sect. 3.2). Although a recent modeling study has suggested that ambient $\mathrm{NH}_{3}$ concentration can be decreased by as much as $31 \%$ in winter and $67 \%$ in summer in the US, due to the reactive uptake of $\mathrm{NH}_{3}$ by secondary carbonyl compounds (Zhu et al., 2018), this process does not appear to have an impact on $\mathrm{NH}_{3}-\mathrm{NH}_{4}^{+}$partitioning and predicted $\mathrm{pH}$ for the locations in this study. For the winter haze conditions in Beijing, which had the highest $\mathrm{pH}$ among the sampling sites, including organic acids (i.e., oxalate) in the model calculation of $\mathrm{pH}$ is reported to only reduce $\mathrm{pH}$ by at most 0.07 (Song et al., 2018).

\section{3 $\mathrm{NO}_{x}$ vs. $\mathrm{NH}_{3}$ control to limit $\mathrm{PM}_{2.5}$ ammonium nitrate?}

Following the various assessments of $\mathrm{NH}_{3}$ control on $\mathrm{PM}_{2.5}$ mass (Erisman and Schaap, 2004; Pinder et al., 2007, 2008; Paulot and Jacob, 2014; Bauer et al., 2016; Pozzer et al., 2017), we assume the $\mathrm{PM}_{2.5}$ inorganic nitrate is mainly in the form of semivolatile ammonium nitrate and negligible in nonvolatile forms, such as $\mathrm{Ca}\left(\mathrm{NO}_{3}\right)_{2}, \mathrm{NaNO}_{3}$, and similar species, which are generally not found to a large extent in particles smaller than $1 \mu \mathrm{m}$. However, it is noted that in locations where concentrations of minerals or sea-salt particle components are high, and the aerosol has aged, formation of semivolatile $\mathrm{NH}_{4} \mathrm{NO}_{3}$ will be perturbed as the $\mathrm{HNO}_{3}$ will evolve over time to the more stable largely coarse-mode salts (e.g., $\mathrm{CaCl}_{2}$ and $\mathrm{NaCl}$ ) at the expense of fine-mode $\mathrm{NH}_{4} \mathrm{NO}_{3}$ (see Guo et al., 2017a, for example).

Aerosol organic nitrate species can also contribute to aerosol mass (Farmer et al., 2010; Perring et al., 2013; Xu et al., 2015), and may respond to $\mathrm{NO}_{x}$ control, but are not considered here. For the 1-year Cabauw data set analyzed here, $9 \%$ of the aerosol nitrate was inferred to be organic nitrate, calculated from the difference in Aerosol Chemical Speciation Monitor (ACSM) nitrate and MARGA-measured nitrate (Schlag et al., 2016). Higher fractions (34\% to $44 \%$ ) have been reported for European submicron aerosols (KiendlerScharr et al., 2016). $\mathrm{NO}_{x}$ emission controls could lead to a change in the relative importance of inorganic and organic nitrate (Edwards et al., 2017).

Focusing just on ammonium nitrate, there are two fundamental ways to control $\mathrm{PM}_{2.5}$ nitrate: (i) limit the precursors of nitrate aerosol, that is $\mathrm{HNO}_{3}$, or (ii) move the nitrate out of the aerosol by reducing the aerosol $\mathrm{pH}$ (increasing the particle acidity). The equilibrium aerosol nitrate concentration is given by

$\mathrm{NO}_{3}^{-}=\varepsilon\left(\mathrm{NO}_{3}^{-}\right) \times \mathrm{NO}_{3}^{\mathrm{T}}$,

where $\mathrm{NO}_{3}^{-}$is the concentration in air of semivolatile aerosol nitrate and $\varepsilon\left(\mathrm{NO}_{3}^{-}\right)$is the fraction of $\mathrm{NO}_{3}^{-}$in the particle phase relative to gas plus particle nitrate $\left(\mathrm{HNO}_{3}+\mathrm{NO}_{3}^{-}\right)$, which is defined as total nitrate, $\mathrm{NO}_{3}^{\mathrm{T}}$. Equation (1) is the definition of $\varepsilon\left(\mathrm{NO}_{3}^{-}\right)$. Because $\varepsilon\left(\mathrm{NO}_{3}^{-}\right)$depends on $\mathrm{pH}$, the premise of $\mathrm{NH}_{3}$ control is to reduce $\varepsilon\left(\mathrm{NO}_{3}^{-}\right)$through decreasing particle $\mathrm{pH}$, whereas $\mathrm{NO}_{x}$ emission controls will mainly reduce $\mathrm{NO}_{3}^{\mathrm{T}}$, although this can also slightly affect $\mathrm{pH}$ through aerosol water uptake (discussed below; see Fig. 4 for example).

$N O_{x}$ control. Emitted $\mathrm{NO}_{x}$ can undergo a variety of reactions that produce a range of compounds $\left(\mathrm{NO}_{z}\right)$, including $\mathrm{HNO}_{3}$, peroxynitric acid $\left(\mathrm{HO}_{2} \mathrm{NO}_{2}\right)$, the nitrate radical $\left(\mathrm{NO}_{3}\right)$, nitrous acid (HONO), dinitrogen pentoxide $\left(\mathrm{N}_{2} \mathrm{O}_{5}\right)$, and both gas-phase (e.g., peroxyacetyl nitrate - PAN) and particle-phase nitrate and organic nitrate species. Once gasphase $\mathrm{HNO}_{3}$ or particle-phase $\mathrm{NO}_{3}^{-}$is formed, equilibrium between the phases will re-establish gas and particle concentrations. $\mathrm{HNO}_{3}$ is largely formed by $\mathrm{NO}_{2}$ reaction with the hydroxyl radical $(\mathrm{OH})$ and at night through the nitrateradical- $\mathrm{N}_{2} \mathrm{O}_{5}$ pathway. Modeling studies show that $\mathrm{HNO}_{3}$ can be the most significant of $\mathrm{NO}_{z}$ species (Atkinson, 2000) and is correlated to $\mathrm{NO}_{x}$ emissions (Shah et al., 2018). Here we assume, to a first approximation, that $\mathrm{NO}_{x}$ mainly produces $\mathrm{HNO}_{3}$ (either directly through reaction with $\mathrm{OH}$ or indirectly through production of $\mathrm{N}_{2} \mathrm{O}_{5}$ ) that partitions to the particle to form semivolatile aerosol nitrate and rapidly reaches equilibrium. $\mathrm{NO}_{3}^{\mathrm{T}}$ concentrations are then directly related to $\mathrm{NO}_{x}$ control. Use of more detailed modeling approaches can better assess the relationship between $\mathrm{NO}_{x}$ emissions and $\mathrm{NO}_{3}^{\mathrm{T}}$. For example, we are not considering competing chemical pathways that lead to organic nitrates versus inorganic nitrate that is in equilibrium with gas-phase $\mathrm{HNO}_{3}$.

$\mathrm{NH}_{3}$ control. The effectiveness of ammonia control in reducing $\mathrm{NH}_{4} \mathrm{NO}_{3}$ burdens depends on $\varepsilon\left(\mathrm{NO}_{3}^{-}\right)$and how it varies with $\mathrm{pH}$, actual $\mathrm{pH}$ of the ambient aerosol, and the sensitivity of ambient aerosol $\mathrm{pH}$ to changes in $\mathrm{NH}_{3}$ concentration. From thermodynamic equilibrium, $\varepsilon\left(\mathrm{NO}_{3}^{-}\right)$can be derived from the solubility, Reaction (R1), and dissociation, Reaction (R2), of $\mathrm{HNO}_{3}$ :

$\mathrm{HNO}_{3(\mathrm{~g})} \leftrightarrow \mathrm{HNO}_{3(\mathrm{aq})}, \quad H_{\mathrm{HNO}_{3}}$
$\mathrm{HNO}_{3(\mathrm{aq})} \leftrightarrow \mathrm{NO}_{3(\mathrm{aq})}^{-}+\mathrm{H}_{(\mathrm{aq})}^{+}, \quad K_{n 1}$. 


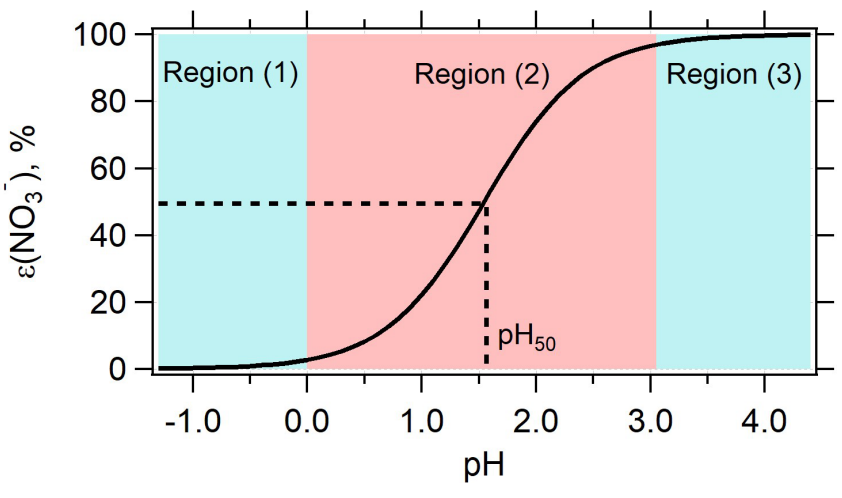

Figure 1. Predicted particle-phase fraction of total nitrate, $\varepsilon\left(\mathrm{NO}_{3}^{-}\right)$, versus $\mathrm{pH}$ for 1-year average condition in Cabauw based on Eq. (2). The blue-color zone denotes where $\mathrm{HNO}_{3}-\mathrm{NO}_{3}^{-}$(nitric acidnitrate) partitioning is not affected by changes in $\mathrm{pH}$, while the red-color zone shows the region where adjusting $\mathrm{pH}$ will change $\mathrm{HNO}_{3}-\mathrm{NO}_{3}^{-}$partitioning and hence $\mathrm{NO}_{3}^{-}$concentration. $\mathrm{NO}_{3}^{-}$is most sensitive to $\mathrm{pH}$ at $\varepsilon\left(\mathrm{NO}_{3}^{-}\right)=50 \%$, which corresponds to a $\mathrm{pH}$ defined as $\mathrm{pH}_{50}$.

Assuming the solution is ideal, $\varepsilon\left(\mathrm{NO}_{3}^{-}\right)$as a function of $\mathrm{pH}$ can be predicted solely based on known properties of $\mathrm{HNO}_{3}$; the $\mathrm{HNO}_{3}$ Henry's constant, $\mathrm{H}_{\mathrm{HNO}_{3}}$, and the acid dissociation constant, $K_{n 1}\left(H_{\mathrm{HNO}_{3}}\right.$ and $K_{n 1}$ are $T$ dependent); ambient $T$; and particle liquid water content. The latter is often estimated by only considering water associated with inorganic species $\left(W_{\mathrm{i}} ; \mu \mathrm{g} \mathrm{m}^{-3}\right)$, determined from measured inorganic aerosol components and relative humidity. Liquid water associated with organic species can also be included but normally has a minor influence on $\mathrm{pH}$ of much lower hygroscopicity and the logarithmic nature of $\mathrm{pH}$ (Guo et al., 2015). A more accurate result may be achieved by using measured particle water concentrations.

By combining the equilibrium of Reactions (R1) and (R2),

$$
\begin{aligned}
& \varepsilon\left(\mathrm{NO}_{3}^{-}\right)= \\
& \frac{H_{\mathrm{HNO}_{3}}{ }^{*} W_{\mathrm{i}} R T\left(0.987 \times 10^{-14}\right)}{\gamma_{\mathrm{NO}_{3}^{-}} \gamma_{\mathrm{H}^{+}} 10^{-\mathrm{pH}}+H_{\mathrm{HNO}_{3}}{ }^{*} W_{\mathrm{i}} R T\left(0.987 \times 10^{-14}\right)},
\end{aligned}
$$

where $0.987 \times 10^{-14}$ is a unit conversion factor (from converting atm and $\mu \mathrm{g}$ to SI units), $R$ ( $\left.\mathrm{J} \mathrm{mol}^{-1} \mathrm{~K}^{-1}\right)$ is the gas constant and $H_{\mathrm{HNO}_{3}}{ }^{*}=H_{\mathrm{HNO}_{3}} K_{n 1}\left(\mathrm{~mol}^{2} \mathrm{~kg}^{-2} \mathrm{~atm}^{-1}\right)$ is the combined molality-based equilibrium constant of $\mathrm{HNO}_{3}$ dissolution and deprotonation, and $\gamma$ represents the activity coefficients (equal to 1 if assuming an ideal solution). Derivation of Eq. (2) and references for the temperature-dependent equilibrium constants, and similar equations for $\mathrm{NH}_{3}$ and $\mathrm{HCl}$ partitioning, can be found in the Supplement of Guo et al. (2017a).

\section{Results and discussions}

\subsection{The nitrate partitioning $S$ curve}

The $\mathrm{S}$ curve given by Eq. (2) provides a conceptual basis for the effect of ammonia control, through changes in aerosol $\mathrm{pH}$, on particle nitrate. Figure 1 shows the characteristic $\mathrm{S}$ shaped curve of $\varepsilon\left(\mathrm{NO}_{3}^{-}\right)$plotted as a function of $\mathrm{pH}$ using Eq. (2), for the yearly average conditions in Cabauw and with activity coefficients extracted from ISORROPIA-II $\left(\gamma_{\mathrm{NO}_{3}^{-}} \gamma_{\mathrm{H}^{+}}=0.24\right)$. Including nonideality shifts the $\varepsilon\left(\mathrm{NO}_{3}^{-}\right)$ $\mathrm{S}$ curve to lower $\mathrm{pH}$ by approximately 0.6 units (shown as Fig. S2).

Figure 1 shows that there are three pertinent $\mathrm{pH}$ regions: (1) low $\mathrm{pH}$, where $\varepsilon\left(\mathrm{NO}_{3}^{-}\right)$asymptotically approaches 0 and practically all $\mathrm{NO}_{3}^{\mathrm{T}}$ is in the gas phase; (2) $\varepsilon\left(\mathrm{NO}_{3}^{-}\right)$varies between approximately 0 and 1 and is highly sensitive to $\mathrm{pH}$ variations; and (3) higher $\mathrm{pH}$, where $\varepsilon\left(\mathrm{NO}_{3}^{-}\right)$approaches 1 and practically all $\mathrm{NO}_{3}^{\mathrm{T}}$ is in the particle phase. This demonstrates that for the 1-year average conditions in Cabauw, there is a certain range in ambient $\mathrm{pH}$ where $\mathrm{NH}_{3}$ control to alter ambient $\mathrm{pH}$ will result in a change in $\mathrm{NO}_{3}^{-}$(i.e., region 2 where $\mathrm{pH}$ is between 0 and 3 ). The greatest change in $\mathrm{NO}_{3}^{-}$to a lowering of $\mathrm{pH}$ occurs when $\varepsilon\left(\mathrm{NO}_{3}^{-}\right)$is near $50 \%$ (referred to as $\mathrm{pH}_{50}$ ).

It follows that $\mathrm{NH}_{3}$ control will only lead to reduction in $\mathrm{NO}_{3}^{-}$if ambient particle $\mathrm{pH}$ is within region 2 of Fig. 1. If $\mathrm{pH}$ is in region 1 there is no need for $\mathrm{NH}_{3}$ control since $\mathrm{pH}$ is sufficiently low that little $\mathrm{NO}_{3}^{-}$exists, and if $\mathrm{pH}$ is in region 3 the sensitivity of $\mathrm{pH}$ to reducing $\mathrm{NH}_{3}$ will determine the effectiveness of $\mathrm{NH}_{3}$ controls. For example, $\mathrm{NH}_{3}$ first needs to be reduced to move particle $\mathrm{pH}$ to the transition point between region 2 and 3, where $\varepsilon\left(\mathrm{NO}_{3}^{-}\right)$starts to drop. (Note that $\mathrm{NH}_{3}$ control also affects particle mass by changing $\mathrm{NH}_{4}^{+}$ concentrations; this is discussed more below in Sect. 3.4.)

The $\mathrm{S}$ curve of Fig. 1 applies for a given situation (see Eq. 2), which changes as the particle composition or ambient conditions (RH, T) change. For example, if $\mathrm{NH}_{3}$ concentrations change, the inorganic particle composition changes, which affects particle water and activity coefficients in Eq. (2), resulting in a shift in the $\varepsilon\left(\mathrm{NO}_{3}^{-}\right)$curve. Thus, these curves provide only a sense of the general state of how $\mathrm{NO}_{3}^{-}$responds to changes in $\mathrm{NH}_{3}$. A full thermodynamic model needs to be run to actually determine the new $\varepsilon\left(\mathrm{NO}_{3}^{-}\right)$ when conditions change. This analysis is provided in the later part of the paper. The $\mathrm{S}$ curve, however, provides valuable insight on sensitivity of $\varepsilon\left(\mathrm{NO}_{3}^{-}\right)$to $\mathrm{pH}$ for a given situation (i.e., what region of Fig. 1). 


\section{2 pH predicted in Cabauw}

High concentrations of aerosol inorganic species were observed during the 1 year of observations at the CESAR tower. The mass fractions of $\mathrm{NO}_{3}^{-}, \mathrm{SO}_{4}^{2-}, \mathrm{NH}_{4}^{+}$, and $\mathrm{Cl}^{-}$were on average $30 \%, 15 \%, 14 \%$, and $1 \%$, respectively, of the $9.5 \mu \mathrm{g} \mathrm{m}^{-3}$ particle mass $\left(\mathrm{PM}_{1}\right)$ (Schlag et al., 2016). The gas-particle partitioning of three semivolatile pairs, $\mathrm{NH}_{3}-$ $\mathrm{NH}_{4}^{+}, \mathrm{HNO}_{3}-\mathrm{NO}_{3}^{-}$, and $\mathrm{HCl}-\mathrm{Cl}^{-}$, measured with MARGA are compared with the thermodynamic model predictions (see Sect. 3 in the Supplement for plots). $\mathrm{PM}_{2.5}$ and $\mathrm{PM}_{1}$ MARGA data sets produce similar results (Fig. S3 versus Fig. S4); here we mainly discuss predictions based on $\mathrm{PM}_{2.5}$. Measured and ISORROPIA-predicted partitioning of ammonia was in agreement $\left(\mathrm{NH}_{3}\right.$ : slope $=1.02$, $R^{2}=0.997 ; \quad \mathrm{NH}_{4}^{+}$: slope $=0.97, R^{2}=0.96$ ) (Fig. S3). $\mathrm{NO}_{3}^{-} \quad$ (slope $\left.=1.01, R^{2}=0.987\right)$ and $\mathrm{Cl}^{-} \quad$ (slope $=0.98$, $R^{2}=0.91$ ) were also in agreement. However, for unknown reasons, gas-phase components of these two species showed significant discrepancies $\left(R^{2}\right.$ of 0.13 to 0.17$)$. We note that these discrepancies may be associated with the very low gas-phase concentrations of these species, in contrast to $\mathrm{NH}_{3} . \mathrm{HNO}_{3}-\mathrm{NO}_{3}^{-}$and $\mathrm{HCl}-\mathrm{Cl}^{-}$were dominated by particle phases, $\varepsilon\left(\mathrm{NO}_{3}^{-}\right)=\mathrm{NO}_{3}^{-} / \mathrm{NO}_{3}^{\mathrm{T}}=88 \pm 11 \%$ and $\varepsilon\left(\mathrm{Cl}^{-}\right)=\mathrm{Cl}^{-} /\left(\mathrm{Cl}^{-}+\mathrm{HCl}\right)=66 \pm 33 \%$. The opposite was found for $\mathrm{NH}_{3}-\mathrm{NH}_{4}^{+}$: the gas phase dominated with $\varepsilon\left(\mathrm{NH}_{4}^{+}\right)=\mathrm{NH}_{4}^{+} / \mathrm{NH}_{x}=19 \pm 15 \%$ (total ammonium is referred to as $\mathrm{NH}_{x}=\mathrm{NH}_{3}+\mathrm{NH}_{4}^{+}$), which is consistent with particle artifacts in the gas collection system possibly affecting $\mathrm{HNO}_{3}$ and $\mathrm{HCl}$, but having less effect on $\mathrm{NH}_{3}$. Furthermore, a generally better prediction of $\mathrm{NH}_{3}-\mathrm{NH}_{4}^{+}$compared to $\mathrm{HNO}_{3}-\mathrm{NO}_{3}^{-}$and $\mathrm{HCl}-\mathrm{Cl}^{-}$partitioning has been observed in our previous studies (Guo et al., 2017a) and is consistent with the lack of a coarse-mode sink for $\mathrm{NH}_{3}$, in contrast to $\mathrm{HNO}_{3}$ and $\mathrm{HCl}$, which can react with sodium and other nonvolatile cations and bias the equilibrium states between fine particles and gases. In summary, all the semivolatile inorganic species in the particle phase $\left(\mathrm{NO}_{3}^{-}, \mathrm{NH}_{4}^{+}\right.$, and $\left.\mathrm{Cl}^{-}\right)$ are predicted with high accuracy, as well as $\mathrm{NH}_{3}-\mathrm{NH}_{4}^{+}$partitioning; therefore, particle water and $\mathrm{pH}$ predictions by ISORROPIA-II are expected to be reasonable.

As noted above, the presence of water-soluble nonvolatile cations (which here include $\mathrm{Na}^{+}, \mathrm{K}^{+}, \mathrm{Ca}^{2+}$, and $\mathrm{Mg}^{2+}$ ) can affect the bulk pH analysis. In Cabauw, NVC effects can be assessed by comparing hourly $\mathrm{PM}_{1}$ and $\mathrm{PM}_{2.5}$ data, since these mechanically generated species are largely found in particles larger than $1 \mu \mathrm{m}$ in diameter. Average NVC mole fractions (i.e., NVCs divided by the total inorganic species, not including liquid water) were consistently small: $5.7 \%$ for $\mathrm{PM}_{1}$ and $5.9 \%$ for $\mathrm{PM}_{2.5}$. However, $\mathrm{Na}^{+}$was slightly higher in $\mathrm{PM}_{2.5}$ at $0.14 \pm 0.25 \mu \mathrm{g} \mathrm{m}^{-3}$, compared to $0.05 \pm$ $0.09 \mu \mathrm{g} \mathrm{m}^{-3}$ for $\mathrm{PM}_{1}$. The small and nearly identical fractions of NVCs result in the same predicted $\mathrm{pH}$ for $\mathrm{PM}_{1}$ and $\mathrm{PM}_{2.5}$; in both cases $\mathrm{pH}=3.7 \pm 0.6$. Therefore, we focus on the $\mathrm{PM}_{2.5}$ in the following discussion due to the similar par-

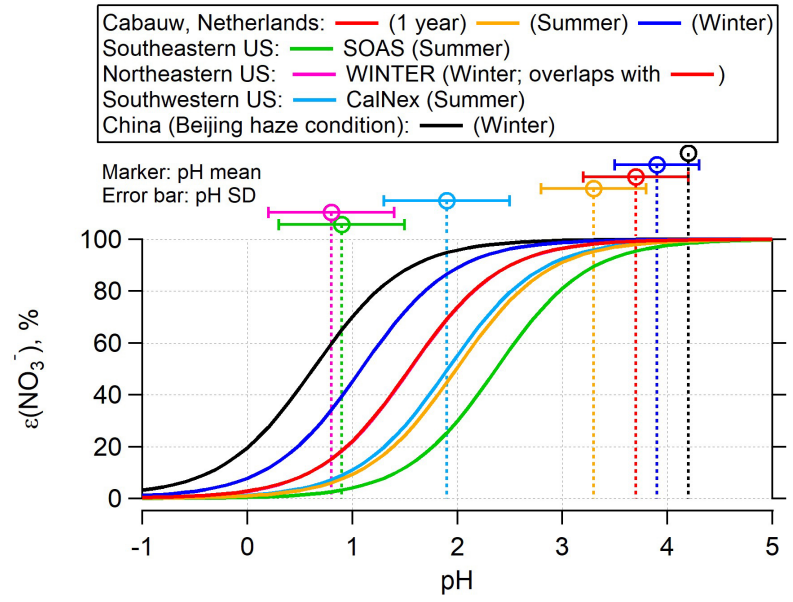

Figure 2. $\varepsilon\left(\mathrm{NO}_{3}^{-}\right)$versus $\mathrm{pH}$ for various field studies based on the average temperature, liquid water, and activity coefficients for each study, according to Eq. (2). The WINTER study curve overlaps completely with the Cabauw 1-year average curve in red color. The input can be found in Table S1. Vertical lines are the study average ambient fine particle $\mathrm{pH}$ calculated with ISORROPIA-II and error bars show the variability in $\mathrm{pH}$ as 1 standard deviation. $\mathrm{S}$ curves and ambient $\mathrm{pH}$ for each site or season can be matched by color. For a more direct comparison between seasons at a specific region, Fig. S5 shows separate curves and ambient $\mathrm{pH}$ plots.

titioning predictions and $\mathrm{pH}$ for $\mathrm{PM}_{1}$ and $\mathrm{PM}_{2.5}$ (Fig. S3 and $\mathrm{S} 4)$. A diurnal pattern of ambient particle $\mathrm{pH}$ is observed in Cabauw, similar to other studies (Guo et al., 2015). For example, for the nighttime period from 01:00 to 07:00, the average $\mathrm{pH}$ is 3.9 , whereas for the daytime period of 13:00 to $18: 00$, the $\mathrm{pH}$ is $\sim 3.5$. The difference is mainly driven by the diurnal variation in liquid water content (see Fig. S1).

\subsection{Contrasts in $\mathrm{pH}$ and $\varepsilon\left(\mathrm{NO}_{3}^{-}\right)$between studies}

Figure 2 includes a comparison of $\varepsilon\left(\mathrm{NO}_{3}^{-}\right)$versus $\mathrm{pH}$ for the different locations and seasons (Fig. S5 shows separate plots for each region). The $\varepsilon\left(\mathrm{NO}_{3}^{-}\right)$curves are plotted based on the campaign average conditions (i.e., $T, W_{\mathrm{i}}$, and $\gamma_{\mathrm{NO}_{3}^{-}} \gamma_{\mathrm{H}^{+}}$; all listed in Table S1). Two sub-data sets in Cabauw, summer (June-August 2012) and winter (December 2012-February 2013), are shown together with the 1year whole data set. As seen for Cabauw, lower temperatures (dark blue vs. red vs. orange lines in Fig. 2) shift $\mathrm{HNO}_{3}$ $\mathrm{NO}_{3}^{-}$partitioning to favor the particle phase due to (i) the effect of $T$ on nitric acid Henry's law and dissociation constants and (ii) the explicit effect of $T$ in Eq. (2). For example, at given activity coefficients and liquid water levels, a decrease from $20(\sim$ summer $)$ to $0^{\circ} \mathrm{C}(\sim$ winter $)$ shifts $\varepsilon\left(\mathrm{NO}_{3}^{-}\right)$ to lower $\mathrm{pH}$ by roughly one unit. The differences between the $\varepsilon\left(\mathrm{NO}_{3}^{-}\right)$curves are also caused by variations in liquid water and to a lesser degree by variation in activity coefficients. 

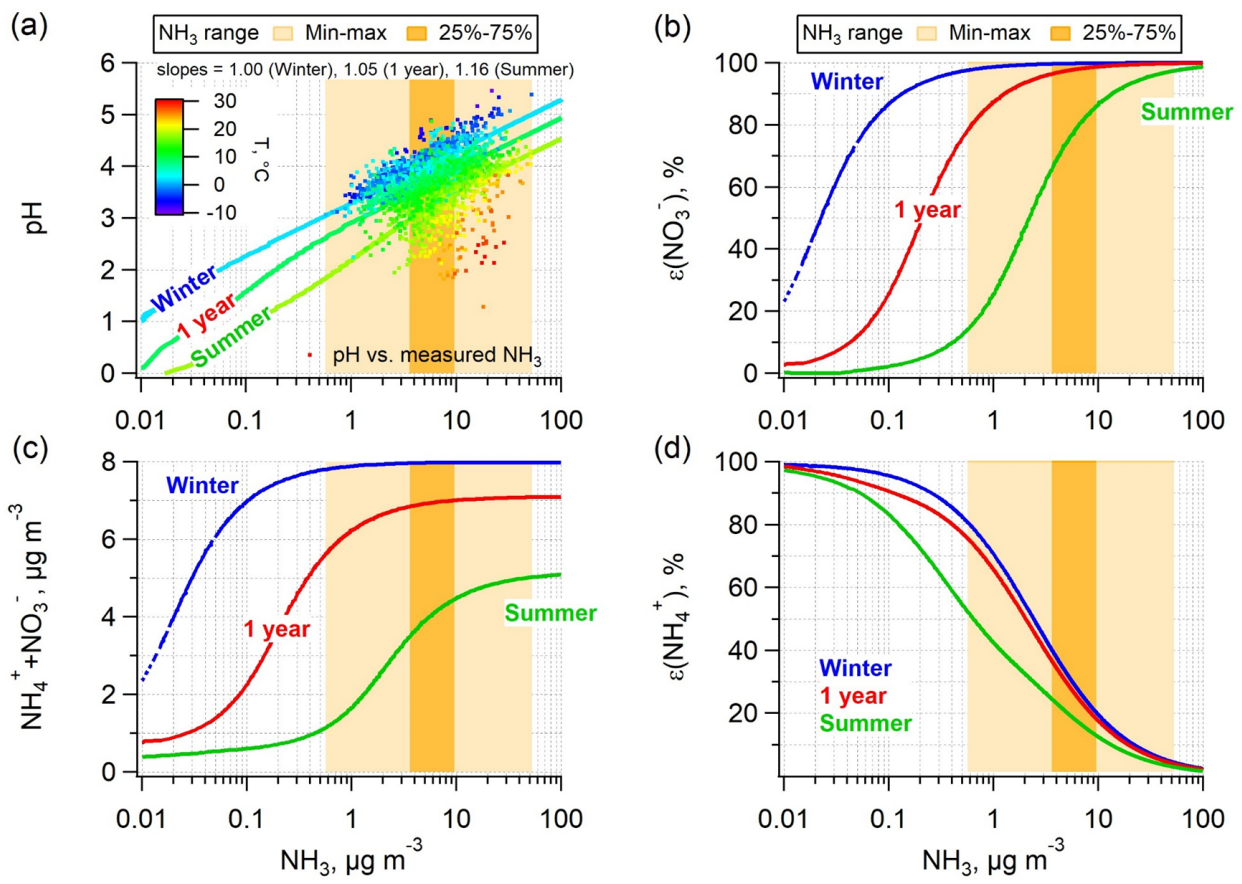

Figure 3. Prediction of (a) particle $\mathrm{pH}$; (b) particle-phase fractions of total nitrate, $\varepsilon\left(\mathrm{NO}_{3}^{-}\right)$; (c) ammonium and nitrate mass concentration; and (d) particle-phase fractions of total ammonium, $\varepsilon\left(\mathrm{NH}_{4}^{+}\right)$, for a wide range of ammonia. The simulations are based on the 1-year (July 2012-June 2013), summer (June-August 2012), and winter (December 2012-February 2013) average conditions at the Cabauw site with $\mathrm{NH}_{x}\left(\mathrm{NH}_{4}^{+}+\mathrm{NH}_{3}\right)$ left as a free variable. The measured $\mathrm{NH}_{3}$ ranges for the 1-year span are also shown as the lighter (min-max) and darker ( $25 \%-75 \%$ percentiles) orange-color zones. Plot (a) also includes the predicted $\mathrm{pH}$ versus measured $\mathrm{NH}_{3}$ data for the entire study and colored by ambient temperature.

In general, the summer curves (the right three curves) are at higher $\mathrm{pH}$ and the winter curves are at lower $\mathrm{pH}$.

In addition to the $\mathrm{S}$ curves, Fig. 2 shows the average ambient particle $\mathrm{pH}$ predicted by ISORROPIA-II for each of the studies. Note that $\mathrm{pH}$ could also be inferred from the $\mathrm{S}$ curve and measured $\varepsilon\left(\mathrm{NO}_{3}^{-}\right)$but is more uncertain and requires activity coefficients for nonideality effects. A comparison between Eq. (2)-predicted $\varepsilon\left(\mathrm{NO}_{3}^{-}\right)$versus $\mathrm{pH}$ and observed $\varepsilon\left(\mathrm{NO}_{3}^{-}\right)$versus ISORROPIA-predicted $\mathrm{pH}$ is shown in Fig. S6 and confirms the consistency between the ISORROPIA-predicted $\mathrm{pH}$ and $\mathrm{S}$ curve given by Eq. (2). (A plot of $\varepsilon\left(\mathrm{NH}_{4}^{+}\right)$vs. pH is also shown in Fig. S6.) Fine ambient particle $\mathrm{pH}$ varies among the sites. The $\mathrm{pH}$ of $3.7 \pm 0.6$ in Cabauw is higher than several other regions, such as the SE US ( $\mathrm{pH}=0.9 \pm 0.6)$, the NE US $(0.8 \pm 1.0)$, and the SW US $(1.9 \pm 0.5)$, but slightly lower than the China haze ambient particle $\mathrm{pH}$ of 4.2. The higher ambient particle $\mathrm{pH}$ is generally associated with higher concentrations of $\mathrm{NH}_{3}$ and $\mathrm{NO}_{3}^{-}$. Particle $\mathrm{pH}$ is affected by coupling between many variables, hence the need for a thermodynamic model. ISORROPIAII predicts the overall resulting equilibrium values and associated $\mathrm{pH}$. Particle nitrate has a secondary effect on $\mathrm{pH}$ by increasing particle liquid water and diluting $\mathrm{H}^{+}$aqueous concentrations, resulting in slightly higher $\mathrm{pH}$. This effect is less pronounced when $\mathrm{SO}_{4}^{2-}$ levels exceed $\mathrm{NO}_{3}^{-}$, meaning that liquid water is mainly controlled by nonvolatile $\mathrm{SO}_{4}^{2-}$. Thus, $\mathrm{NH}_{3}, \mathrm{NO}_{3}^{-}$, and particle $\mathrm{pH}$ are coupled. Regions of higher $\mathrm{NH}_{3}$ will have higher $\mathrm{pH}$, which can lead to higher $\mathrm{NO}_{3}^{-}$(when in region 2 of Fig. 1). The highest observed $\mathrm{NH}_{3}$ $\left(12.8 \mu \mathrm{g} \mathrm{m}^{-3}\right)$ and $\mathrm{NO}_{3}^{-}\left(26 \mu \mathrm{g} \mathrm{m}^{-3}\right)$ concentrations were found for the Beijing haze condition. The Cabauw 1-year average $\mathrm{NH}_{3}$ was lower at $7.3 \mu \mathrm{g} \mathrm{m}^{-3}$, and $\mathrm{NO}_{3}^{-}$was on average $4.7 \mu \mathrm{g} \mathrm{m}^{-3}$. The lowest $\mathrm{NH}_{3}$ and $\mathrm{NO}_{3}^{-}$levels were observed in the US studies: for example, $1.37 \mu \mathrm{g} \mathrm{m}^{-3} \mathrm{NH}_{3}$ and $3.58 \mu \mathrm{g} \mathrm{m}^{-3} \mathrm{NO}_{3}^{-}$in the SW US, and only $0.39 \mu \mathrm{g} \mathrm{m}^{-3} \mathrm{NH}_{3}$ and $0.08 \mu \mathrm{g} \mathrm{m}^{-3} \mathrm{NO}_{3}^{-}$in the SE US, both in summer.

The intersection of the $\varepsilon\left(\mathrm{NO}_{3}^{-}\right) \mathrm{S}$ curves with ambient particle pH in Fig. 2 (i.e., intersection of vertical line and corresponding site $\mathrm{S}$ curve) provides contrast in the average $\varepsilon\left(\mathrm{NO}_{3}^{-}\right)$at each site and hence how much $\mathrm{NH}_{3}$ control will be needed to shift $\varepsilon\left(\mathrm{NO}_{3}^{-}\right)$to $50 \%$ and a corresponding $\mathrm{pH}$ of $\mathrm{pH}_{50}$. The lowest $\varepsilon\left(\mathrm{NO}_{3}^{-}\right)$was found in the SE US at $22 \%$ in summer and a higher $\varepsilon\left(\mathrm{NO}_{3}^{-}\right)$in the NE US in winter at $39 \%$. The Cabauw site also had higher $\varepsilon\left(\mathrm{NO}_{3}^{-}\right)$in winter (91\%) than summer (84\%). Additionally, the SW US site observed on average $54 \% \varepsilon\left(\mathrm{NO}_{3}^{-}\right)$in summer and the China haze had $\sim 100 \% \varepsilon\left(\mathrm{NO}_{3}^{-}\right)$in winter. These data show that, in the SE US in summer, $\varepsilon\left(\mathrm{NO}_{3}^{-}\right)$is generally so low that 
shifting $\mathrm{pH}$ by changing $\mathrm{NH}_{3}$ emissions will not greatly influence $\mathrm{NH}_{4} \mathrm{NO}_{3}$ concentrations since most of it is already in the gas phase. Higher $\mathrm{NH}_{3}$ can increase $\mathrm{NH}_{4} \mathrm{NO}_{3}$, but large changes in $\mathrm{NH}_{3}$ are needed in these regions to change $\mathrm{pH}$ (Weber et al., 2016). For the SW US summer, $\mathrm{NO}_{3}^{-}$partitioning is sensitive to changes in $\mathrm{pH}$ with a $54 \% \varepsilon\left(\mathrm{NO}_{3}^{-}\right)$. In the Beijing winter, substantial decrease in $\mathrm{pH}$ is needed to evaporate $\mathrm{NH}_{4} \mathrm{NO}_{3}$, even more so than Cabauw in winter. For Cabauw, a substantial reduction in ambient $\mathrm{pH}$ would be needed to evaporate $\mathrm{NO}_{3}^{-}$since the current $\mathrm{pH}$ is on the flat zone of the $\mathrm{S}$ curve (region 3), where $\varepsilon\left(\mathrm{NO}_{3}^{-}\right)$is near $100 \%$. In summer, however, a much smaller reduction in ambient particle $\mathrm{pH}$ would result in a decrease in $\mathrm{NO}_{3}^{-}$.

\subsection{Simulation of particle mass reduction with a thermodynamic model}

\subsubsection{Sensitivities of $\mathrm{pH}$ and nitrate partitioning to $\mathrm{NH}_{3}$ concentration}

In the above analysis, $\varepsilon\left(\mathrm{NO}_{3}^{-}\right)$versus $\mathrm{pH}$ curves relative to ambient particle $\mathrm{pH}$ are used to provide insight on how $\varepsilon\left(\mathrm{NO}_{3}^{-}\right)$is expected to change with small changes in $\mathrm{pH}$. The $\mathrm{S}$ curves are based on the average ambient conditions for each time period, and variables, such as particle water and activity coefficients, are held constant. But changes in $\mathrm{NH}_{3}$ concentration will vary aerosol composition, liquid water content, and the activity coefficients, which in turn modulates the $\mathrm{S}$ curve, Eq. (2). To address this, in the following analysis, we run ISORROPIA-II for various input $\mathrm{NH}_{x}$ concentrations, while $T, \mathrm{RH}, \mathrm{NO}_{3}^{\mathrm{T}}$, and $\mathrm{SO}_{4}^{2-}$ are held constant, and plot various parameters of interest. This takes into account the various aerosol composition and gas-phase species concentrations through the consideration of the partitioning of all semivolatile species, including water, and how this affects thermodynamic properties, such as activity coefficients.

First, we consider the extent of $\mathrm{NH}_{3}$ control needed to reduce $\mathrm{NH}_{4} \mathrm{NO}_{3}$, which depends on the response of $\mathrm{pH}$ to changes in ambient $\mathrm{NH}_{3}$ concentration, which in turn is related to $\mathrm{NH}_{3}$ emissions (i.e., changes in $\mathrm{NH}_{x}$ ). In a previous study, we show that for average conditions at the various sites discussed above, a general rule is that an order of magnitude reduction in $\mathrm{NH}_{3}$ lowers $\mathrm{pH}$ by about one unit (Guo et al., 2017c) $\left(\Delta \mathrm{pH} / \Delta\left(\log _{10} \mathrm{NH}_{3}\right)\right.$ are listed in Table S1). At the Cabauw site, the responses in $\mathrm{pH}$ to changes in $\mathrm{NH}_{3}$ are similar to these other locations; the linear fitted curves for the semi-log plot in Fig. 3a give slopes of 1.00 in winter, 1.16 in summer and 1.05 for the 1 -year average (all $R^{2}>0.99$ ). Figure $3 \mathrm{a}$ also shows predicted $\mathrm{pH}$ versus measured $\mathrm{NH}_{3}$ based on hourly average data. How pH changes with temperature for a constant $\mathrm{NH}_{3}$ can also be seen in Fig. 3a; higher temperature leads to lower particle $\mathrm{pH}$ due to volatilization of semivolatile $\mathrm{NH}_{4}^{+}, \mathrm{NO}_{3}^{-}$, and particle water. The physical explanation for this is that, with higher temperature, $\mathrm{NH}_{4}^{+}$is converted to $\mathrm{NH}_{3}$ and releases one $\mathrm{H}^{+}$to the particle phase, whereas $\mathrm{NO}_{3}^{-}$is converted to $\mathrm{HNO}_{3}$ and results in loss of one $\mathrm{H}^{+}$from the particle phase. The former process dominates over the latter due to the differences in the temperature dependency of equilibrium constants (see Fig. S7) and the greater loss of $\mathrm{NH}_{4}^{+}$from $\mathrm{NH}_{4} \mathrm{NO}_{3}$ and $\left(\mathrm{NH}_{4}\right)_{2} \mathrm{SO}_{4}$ compared to less loss of $\mathrm{NO}_{3}^{-}$only from $\mathrm{NH}_{4} \mathrm{NO}_{3}$, leading to a net increase in particle $\mathrm{H}^{+}$and lower $\mathrm{pH}$. The loss of water associated with $\mathrm{NH}_{4}^{+}$and $\mathrm{NO}_{3}^{-}$further reduces $\mathrm{pH}$, as the $\mathrm{H}^{+}$ becomes more concentrated. The water effect is also seen in the diurnal $\mathrm{pH}$ trends (see Fig. S1b).

This analysis also permits assessing how $\varepsilon\left(\mathrm{NO}_{3}^{-}\right)$, the sum of $\mathrm{NH}_{4}^{+}$and $\mathrm{NO}_{3}^{-}\left(\mathrm{NH}_{4}^{+}+\mathrm{NO}_{3}^{-}\right)$, and $\varepsilon\left(\mathrm{NH}_{4}^{+}\right)$responds to changes in $\mathrm{NH}_{3}$. Figure $3 \mathrm{~b}$ shows that it takes a factor of 1000 change in $\mathrm{NH}_{3}$ concentration $(\sim 3 \mathrm{pH}$ units) to reduce $\varepsilon\left(\mathrm{NO}_{3}^{-}\right)$from $\sim 100 \%$ to $\sim 0 \%$ (i.e., from complete particle phase to complete gas phase). Also, a change temperature of $\sim 8^{\circ} \mathrm{C}$ shifts $\varepsilon\left(\mathrm{NO}_{3}^{-}\right)$equivalent to roughly an order of magnitude change in $\mathrm{NH}_{3}$ concentration. (For reference, $\Delta T$ between winter and 1-year averages is $6.6^{\circ} \mathrm{C}$ and $\Delta T$ between 1 -year average and summer averages is $8.8^{\circ} \mathrm{C}$ ). Figure $3 \mathrm{~b}$ and $\mathrm{c}$ again show that larger reductions in $\mathrm{NH}_{3}$ are needed in winter compared to summer to reduce $\mathrm{NO}_{3}^{-}$. In Cabauw, only during the highest temperature periods is a $\mathrm{NH}_{3}$ control policy immediately effective.

The response of $\varepsilon\left(\mathrm{NH}_{4}^{+}\right)$to changes in $\mathrm{NH}_{3}$ is shown in Fig. 3d. The $\mathrm{S}$ curves are reversed compared to $\varepsilon\left(\mathrm{NO}_{3}^{-}\right)$due to opposite base and acid partitioning responses to changes in $\mathrm{pH}$. Thus, lowering $\mathrm{NH}_{3}$ reduces $\varepsilon\left(\mathrm{NO}_{3}^{-}\right)$, reducing $\mathrm{NO}_{3}^{-}$ for constant $\mathrm{NO}_{3}^{\mathrm{T}}$, but raises $\varepsilon\left(\mathrm{NH}_{4}^{+}\right)$as the particles become more acidic, resulting in relatively more $\mathrm{NH}_{4}^{+}$in the particle phase and less $\mathrm{NH}_{3}$ in the gas phase. This is important since although we discuss $\mathrm{NH}_{3}$ emissions, changes in particle $\mathrm{pH}$ also affect $\mathrm{NH}_{3}$ concentrations through changes in gas-particle partitioning (i.e., $\left.\varepsilon\left(\mathrm{NH}_{4}^{+}\right)\right)$, but it is $\mathrm{NH}_{x}$ that is really changing through emission controls.

Finally, Fig. 3d shows that temperature has little effect on the $\varepsilon\left(\mathrm{NH}_{4}^{+}\right)$versus $\mathrm{NH}_{3}$ curves. This is because for constant $W_{\mathrm{i}}$ and activity coefficients, the $\varepsilon\left(\mathrm{NH}_{4}^{+}\right)$versus $\mathrm{pH} \mathrm{S}$ curves move in the opposite direction with change in temperature than the $\varepsilon\left(\mathrm{NO}_{3}^{-}\right)$versus $\mathrm{pH} \mathrm{S}$ curves; $\varepsilon\left(\mathrm{NH}_{4}^{+}\right)$shifts to a lower $\mathrm{pH}$ region and $\varepsilon\left(\mathrm{NO}_{3}^{-}\right)$shifts to a higher $\mathrm{pH}$ region with increasing temperature. This tends to bring the $\mathrm{NH}_{3}-$ $\mathrm{NH}_{4}^{+}$partitioning versus $\mathrm{NH}_{3}$ curves together and separate the $\mathrm{HNO}_{3}-\mathrm{NO}_{3}^{-}$partitioning versus $\mathrm{NH}_{3}$ curves for different seasons, considering an increase in $\mathrm{pH}$ at lower temperature and constant $\mathrm{NH}_{3}$ shown in Fig. 3a or vice versa.

\subsubsection{Effects of $\mathrm{NH}_{3}, \mathrm{NO}_{x}$, and $\mathrm{SO}_{2}$ emission control in Cabauw}

Here we assess the relative merits of $\mathrm{NH}_{3}, \mathrm{NO}_{x}$, and $\mathrm{SO}_{2}$ control on various aspects of $\mathrm{PM}_{2.5}$ in Cabauw, again using the full thermodynamic model. Changes in $\mathrm{pH}$, particle water $\left(W_{\mathrm{i}}\right), \varepsilon\left(\mathrm{NO}_{3}^{-}\right)$, mass of $\mathrm{NH}_{4}^{+}$plus $\mathrm{NO}_{3}^{-}$, and overall $\mathrm{PM}_{2.5}$ ion mass are assessed when changes are made to $\mathrm{NH}_{x}$ 

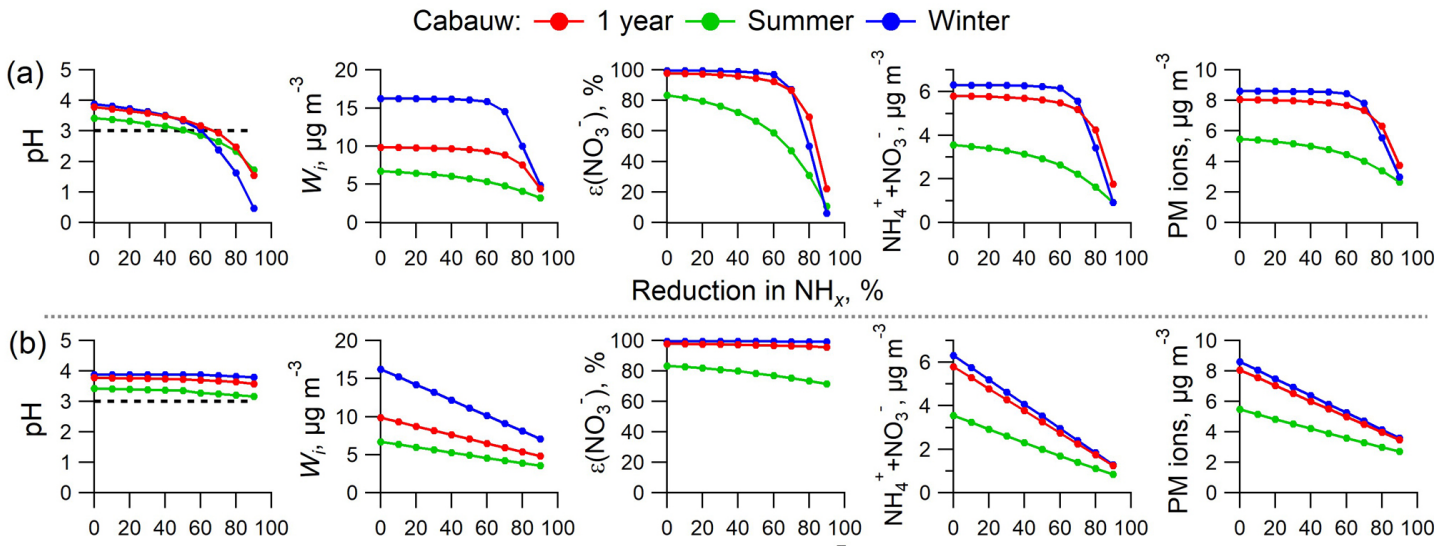

Reduction in $\mathrm{NH}_{x}, \%$
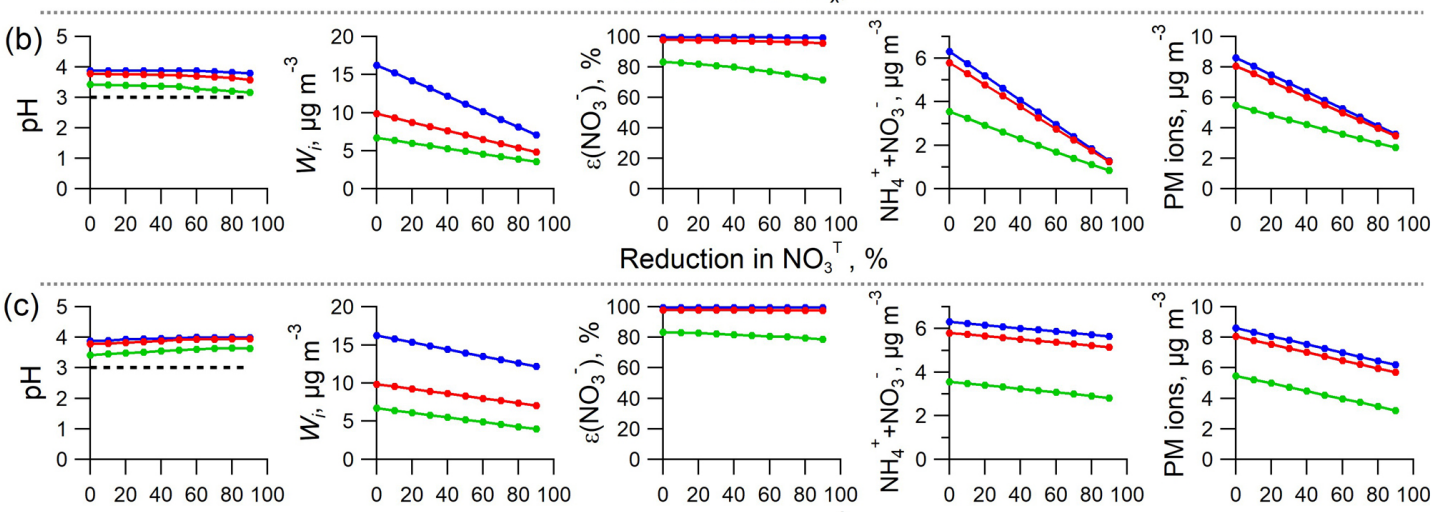

\section{Reduction in $\mathrm{NO}_{3}{ }^{\top}, \%$}
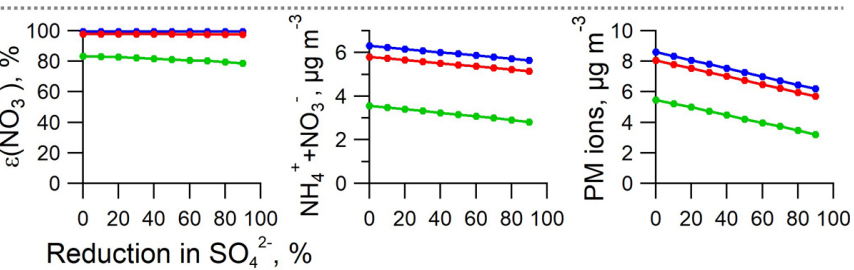

Figure 4. ISORROPIA-predicted $\mathrm{PM}_{2.5} \mathrm{pH}$ (first column), liquid water content ( $W_{\mathrm{i}}$, second column), $\varepsilon$ ( $\mathrm{NO}_{3}^{-}$) (third column), ammonium and nitrate (fourth column), and aerosol inorganic mass concentrations (fifth column) as a function of changes in $\mathrm{NH}_{x}\left(\mathrm{NH}_{4}^{+}+\mathrm{NH}_{3}\right.$, first row), $\mathrm{NO}_{3}^{\mathrm{T}}\left(\mathrm{NO}_{3}^{-}+\mathrm{HNO}_{3}\right.$, second row), and $\mathrm{SO}_{4}^{2-}$ (third row). Simulations are based on average conditions of 1-year, summer, and winter observational data in Cabauw, the Netherlands, and changing only $\mathrm{NH}_{x}, \mathrm{NO}_{3}^{\mathrm{T}}$, and $\mathrm{SO}_{4}^{2-}$ from the average conditions. The black dashed lines in the $\mathrm{pH}$ figures identify the critical $\mathrm{pH}$ value of 3 .

$\left(\mathrm{NH}_{3}+\mathrm{NH}_{4}^{+}\right), \mathrm{NO}_{3}^{\mathrm{T}}\left(\mathrm{HNO}_{3}+\mathrm{NO}_{3}^{-}\right)$, and $\mathrm{SO}_{4}^{2-}$, representing control of $\mathrm{NH}_{3}, \mathrm{NO}_{x}$, and $\mathrm{SO}_{2}$ emissions, respectively. Each are reduced in steps starting from $0 \%$ to a $90 \%$ reduction, while holding the other model inputs constant. The results are shown in Fig. 4. The base values are the 1-year, summer, and winter average conditions and correspond to $0 \%$ reduction in all plots.

The first row in Fig. 4 shows that all parameters respond nonlinearly to $\mathrm{NH}_{x}$ reduction, remaining relatively constant until $\sim 70 \% \mathrm{NH}_{x}$ reduction, at which point they start to rapidly decrease. This is a result of the $\varepsilon\left(\mathrm{NO}_{3}^{-}\right)$versus $\mathrm{pH}$ $\mathrm{S}$ curve of Fig. 1, where little effect is realized until $\mathrm{pH}$ reaches a critical value of about 3 (the horizontal dashed line in Fig. 4 pH plots). Once pH drops below this, the balance between $\mathrm{HNO}_{3}$ and $\mathrm{NO}_{3}^{-}$is sharply shifted towards the gas phase due to the combined effects of reduced particle $\mathrm{pH}$ and also reduced particle water $\left(W_{\mathrm{i}}\right)$. An approximate $70 \%$ reduction in $\mathrm{NH}_{x}$ is required in Cabauw, in winter or based on the yearly average data, to achieve effective reductions in $\left(\mathrm{NH}_{4}^{+}+\mathrm{NO}_{3}^{-}\right)$and particle ion mass. In summer, some minor reductions in the mass concentrations occur for small $\mathrm{NH}_{x}$ reductions, since $\mathrm{pH}$ is slightly lower in summer (3.3) compared to winter (3.9). Despite the seasonal variations in gas and particle composition, $\mathrm{RH}$, and $T$, all three $\mathrm{pH}$ curves ( 1 year, summer, winter) appear to be similar and show a critical $\mathrm{pH}$ of approximately $3 ; \mathrm{NH}_{x}$ reduction is more effective for $\mathrm{pH}$ below 3 but far less effective for $\mathrm{pH}$ above 3, consistent with the simplified analysis above (see Fig. 1).

Effects of reducing $\mathrm{NO}_{3}^{\mathrm{T}}$ (the second row, Fig. 4b, i.e., $\mathrm{NO}_{x}$ control) and $\mathrm{SO}_{4}^{2-}$ (the third row, i.e., $\mathrm{SO}_{2}$ control) show different responses. For $\mathrm{NO}_{x}$ control, holding $\mathrm{NH}_{x}$ and $\mathrm{SO}_{4}^{2-}$ constant, a linear reduction in $\mathrm{NO}_{3}^{\mathrm{T}}$ causes a linear decrease in $W_{\mathrm{i}}$, $\left(\mathrm{NH}_{4}^{+}+\mathrm{NO}_{3}^{-}\right)$, and $\mathrm{PM}_{2.5}$ ion concentrations simply because $\varepsilon\left(\mathrm{NO}_{3}^{-}\right)$remains close to 1 so that $\mathrm{NO}_{3}^{-}$ $\sim \mathrm{NO}_{3}^{\mathrm{T}}$. Then a reduction $\mathrm{NO}_{3}^{\mathrm{T}}$ is just transmitted directly to $W_{\mathrm{i}}\left(\mathrm{SO}_{4}^{2-}\right.$ is constant so particle hygroscopicity is controlled by $\left.\mathrm{NO}_{3}^{-}\right),\left(\mathrm{NH}_{4}^{+}+\mathrm{NO}_{3}^{-}\right)$, and $\mathrm{PM}_{2.5}$ ions. $\varepsilon\left(\mathrm{NO}_{3}^{-}\right)$is relatively constant (more so in winter) because it is $\sim 100 \%$ and so not sensitive to the changes in $W_{\mathrm{i}}$. Lower $W_{\mathrm{i}}$ does shift the $\mathrm{HNO}_{3}-\mathrm{NO}_{3}^{-} \mathrm{S}$ curve towards a higher $\mathrm{pH}$, but since $\mathrm{pH}$ is affected little, and never drops below the critical value of 3 , $\mathrm{HNO}_{3}-\mathrm{NO}_{3}^{-}$partitioning is barely affected by reducing $\mathrm{NO}_{3}^{\mathrm{T}}$ (i.e., remains in region 3 in Fig. 1)

In the case of $\mathrm{SO}_{4}^{2-}$ reduction, particle $\mathrm{pH}$ only increases slightly with substantial $\mathrm{SO}_{4}^{2-}$ reduction due to buffering by $\mathrm{NH}_{3}-\mathrm{NH}_{4}^{+}$partitioning (i.e., $\mathrm{NH}_{4}^{+}$volatility) (Weber et al., 2016; Guo et al., 2017c). $\left(\mathrm{NH}_{4}^{+}+\mathrm{NO}_{3}^{-}\right)$decreases slightly due to the loss of associated $\mathrm{NH}_{4}^{+}$due to both the drop in $\mathrm{SO}_{4}^{2-}$ and volatilization caused by reduced particle water. Since $\mathrm{SO}_{4}^{2-}$ is nonvolatile and no gas-particle partitioning is involved, the $\mathrm{SO}_{4}^{2-}$ reduction results in a linear reduction 


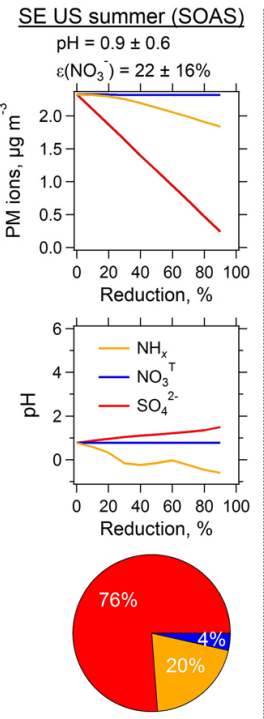

(a)
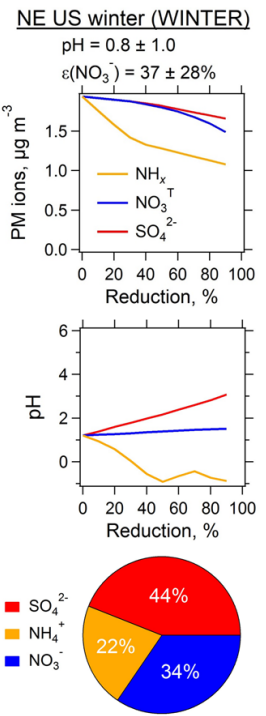

(b)
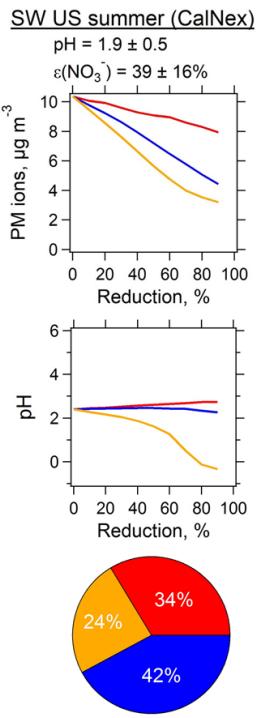

(c)
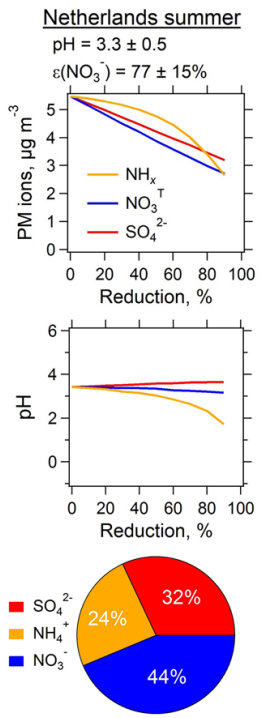

(d)
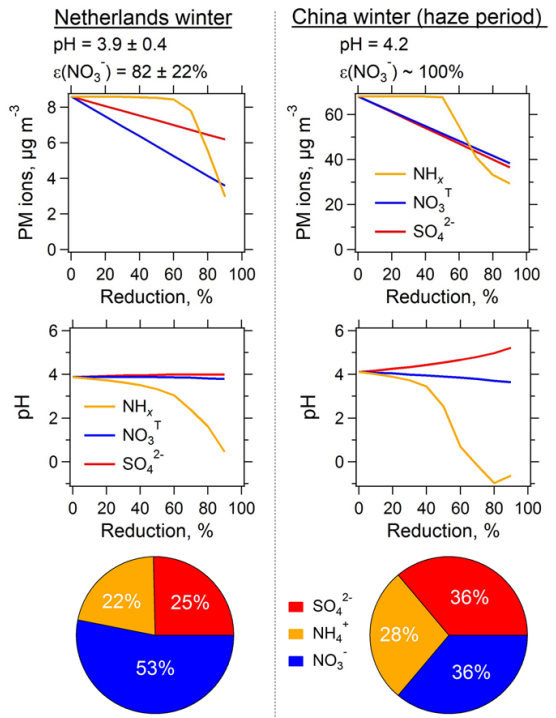

(e)

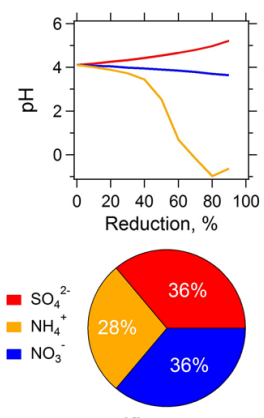

(f)

Figure 5. Response of predicted $\mathrm{PM}_{2.5}$ inorganic mass concentration (first row) and $\mathrm{pH}$ (second row) to reduced levels of $\mathrm{NH}_{x}$ $\left(\mathrm{NH}_{3}+\mathrm{NH}_{4}^{+}\right), \mathrm{NO}_{3}^{\mathrm{T}}\left(\mathrm{HNO}_{3}+\mathrm{NO}_{3}^{-}\right)$, and $\mathrm{SO}_{4}^{2-}$ for several studies including (a) the southeastern US summer at a rural ground site in Centreville, AL (SOAS study); (b) the northeastern US during winter (WINTER aircraft study); (c) the southwestern US summer at an urban site in Pasadena, CA (CalNex study); (d, e) the Netherlands summer and winter conditions at a rural site in Cabauw from this study; and (f) polluted winter conditions (haze) in Beijing, China. For each case, the average fine ambient particle $\mathrm{pH}$ and $\varepsilon\left(\mathrm{NO}_{3}^{-}\right)$, prior to the reductions, are shown above the figures, with the columns ordered with increasing ambient particle $\mathrm{pH}$ from left to right. $\mathrm{PM}_{2.5} \mathrm{mass}$ fractions of $\mathrm{NH}_{4}^{+}-\mathrm{SO}_{4}^{2-}-\mathrm{NO}_{3}^{-}$based on study averages are shown as pie graphs along the bottom.

in particle ionic mass, while model input of $\mathrm{NH}_{x}$ and $\mathrm{NO}_{3}^{\mathrm{T}}$ is constant.

Sensitivity tests were also performed to investigate the robustness of these results. Considering the observed decreasing trends of $\mathrm{SO}_{2}$ emissions in many regions (Hand et al., 2012; Hidy et al., 2014; Warner et al., 2017), we tested a cleaner future with less sulfate $(20 \%$ of the current level; see Fig. S8). Also, since significant changes in global climate and surface land cover can result in a dustier future with more NVCs, we investigated the effect of a $400 \%$ increase in NVCs above the Cabauw levels (see Fig. S9). These two assumed scenarios produce a similar conclusion as the base simulation discussed above, including our finding of a critical $\mathrm{pH}$ of 3 and nonlinear response to a $\mathrm{NH}_{x}$ reduction. However, we note that, in the reduced $\mathrm{SO}_{4}^{2-}$ case (i.e., the cleaner future scenario), $\mathrm{SO}_{4}^{2-}$ control had nearly no effect on particle ion mass because the $\mathrm{SO}_{4}^{2-}$ concentrations were already very low.

In summary, the optimal strategy to reduce ammonium nitrate or particle total inorganic ion mass for the current conditions in Cabauw is to control $\mathrm{NO}_{3}^{\mathrm{T}}\left(\mathrm{NO}_{x}\right.$ emission) since it results in a linear response. Even $\mathrm{SO}_{4}^{2-}$ control is superior over $\mathrm{NH}_{x}$ control to reduce particle ion mass, unless over $70 \%$ reduction in $\mathrm{NH}_{x}$ could be achieved. If $\mathrm{NH}_{x}$ is reduced, the effects will be greatest in warmer periods. These are also the times when $\mathrm{NH}_{3}$ emissions and concentrations are largest regionally or globally (Yamamoto et al., 1988; Warner et al., 2016, 2017; Zhang et al., 2018) (see Table S1 for Cabauw $\mathrm{NH}_{3}$ levels), and so there may be other benefits to controlling $\mathrm{NH}_{3}$ emissions at these times, for example, minimizing eutrophication in surface aqueous systems.

The above findings in Cabauw are in contrast to results of a global model, which also utilized ISORROPIA-II (Pozzer et al., 2017). They find the impacts of $\mathrm{NH}_{3}$ emissions on $\mathrm{PM}_{2.5}$ mass are strongest in winter for Europe (along with North America and Asia). Some of the differences are likely attributed to our higher predicted $\mathrm{pH}$ in Cabauw of $\sim 3.7 \mathrm{com}-$ pared to the average $\mathrm{pH}$ of Europe predicted in the global model to be near 2 (Pozzer et al., 2017). Thus, we predict conditions above the critical $\mathrm{pH}$ of 3 , and Pozzer et al. (2017) predicts $\mathrm{pH}$ below this value. Difference in $\mathrm{pH}$ may be due to meteorological conditions or the concentration of aerosol and gas inorganic species, but it does demonstrate the sensitivity of responses to what the local ambient $\mathrm{pH}$ is and that care should be taken to evaluate predicted particle $\mathrm{pH}$ against inferences from ambient measurements. Another thermodynamic model may give a different $\mathrm{pH}$ compared to ISORROPIA-II, which may result in a slightly different critical $\mathrm{pH}$ (i.e., $\sim 3$ in this study). Next, we explore the outcomes of $\mathrm{NH}_{x}$ reductions in other locations and show that $\mathrm{NH}_{3}$ emission control is more effective in winter than summer. 


\subsubsection{Effects of $\mathrm{NH}_{3}, \mathrm{NO}_{x}$, and $\mathrm{SO}_{2}$ emission control for other locations}

$\mathrm{NH}_{x}, \mathrm{NO}_{3}^{\mathrm{T}}$, and $\mathrm{SO}_{4}^{2-}$ reduction tests were also run for the other sampling sites following the same approach as described above for Cabauw. The model input (period averages) can be found in Table $\mathrm{S} 1$ and the results summarized in Fig. 5. The Cabauw simulations are included in Fig. 5 for direct comparison with the other studies, despite being also plotted in Fig. 4. The average fine particle $\mathrm{pH}$ and $\varepsilon\left(\mathrm{NO}_{3}^{-}\right)$ in each study are listed at the top of each plot in Fig. 5 and the plots for the different studies are arranged with increasing ambient $\mathrm{pH}$ from left to right. This order is followed in the following discussion.

Fine particles in the eastern US (SOAS and WINTER studies, Fig. 5a and b) are the most acidic among the sites, with an average $\mathrm{pH}$ of approximately 1 due to the lowest $\mathrm{NH}_{3}$ (and to some minor extent due to small $\mathrm{NO}_{3}^{-}$, through its effect on liquid water). In the NE US in winter, $\mathrm{NH}_{x}$ control is most efficient in decreasing $\mathrm{PM}_{2.5}$ ion mass since the particle $\mathrm{pH}$ and $\varepsilon\left(\mathrm{NO}_{3}^{-}\right)(37 \%)$ indicate a sweet spot, where the change in $\mathrm{NH}_{x}$ emission affects $\mathrm{NO}_{3}^{-}$immediately. $\mathrm{PM}_{2.5}$ ion mass reductions from $\mathrm{NO}_{3}^{\mathrm{T}}$ control and $\mathrm{SO}_{4}^{2-}$ control are similar, since aerosol $\mathrm{NO}_{3}^{-}$and $\mathrm{SO}_{4}^{2-}$ are comparable in mass. In the SE US in summer, $\mathrm{NO}_{3}^{\mathrm{T}}$ control is not effective because $\mathrm{NO}_{3}^{-}$only contributed $4 \%$ to the $\mathrm{NH}_{4}^{+}-\mathrm{SO}_{4}^{2-}-\mathrm{NO}_{3}^{-}$ aerosols (Fig. 5a). A small fraction of nitrate aerosol is typically observed in the southeast in summer (Hidy et al., 2014) due to the high temperature and low particle $\mathrm{pH}$. Because of the small $\mathrm{NO}_{3}^{-}$fraction and already low $\mathrm{pH}$ in summer, $\mathrm{NH}_{x}$ control only leads to minor reductions in particle ionic mass. In contrast, $\mathrm{SO}_{4}^{2-}$ control produces the highest reduction of particle ionic mass since it is the dominant inorganic species (76\%) in this region. Therefore, it is more effective to control $\mathrm{NH}_{x}$ in winter in the NE US and $\mathrm{SO}_{4}^{2-}$ in summer in the SE US, a finding consistent with previous studies (Duyzer, 1994; Tsimpidi et al., 2007).

For the southwestern US summer (CalNex study, Fig. 5c), since $\mathrm{NO}_{3}^{-}$was the most abundant among $\mathrm{NH}_{4}^{+}-\mathrm{SO}_{4}^{2-}-\mathrm{NO}_{3}^{-}$ aerosol components, reducing $\mathrm{NH}_{x}$ is the most effective way to reduce $\mathrm{PM}_{2.5}$ ion mass as the ambient particle $\mathrm{pH}$ is within the range where $\varepsilon\left(\mathrm{NO}_{3}^{-}\right)$is sensitive to $\mathrm{pH}$. $\mathrm{NO}_{3}^{\mathrm{T}}$ control follows closely in effectiveness, whereas reducing $\mathrm{SO}_{4}^{2-}$ is the least effective. In the WINTER (NE US winter) and CalNex (SW US summer) studies, $\mathrm{PM}_{2.5}$ ion mass decreases at a lower rate towards higher levels in $\mathrm{NH}_{x}$ reduction (see Fig. $5 b$ and c) due to the nonlinear response in $\varepsilon\left(\mathrm{NO}_{3}^{-}\right)$to $\mathrm{NH}_{3}$ concentration (as shown in Figs. 3b or 2). For instance, when $\varepsilon\left(\mathrm{NO}_{3}^{-}\right)$drops from $50 \%$ to $0 \%$, the sensitivities to $\mathrm{NH}_{3}$ keep decreasing asymptotically towards zero. The $\mathrm{pH}$ stays nearly flat for the $\mathrm{NO}_{3}^{\mathrm{T}}$ control and $\mathrm{SO}_{4}^{2-}$ control and decreases with the $\mathrm{NH}_{x}$ control.

Cabauw winter and Beijing winter haze conditions (see Fig. 5e and f) are similar in terms of benefits in reducing particle ionic mass from $\mathrm{NH}_{x}, \mathrm{NO}_{3}^{\mathrm{T}}$, or $\mathrm{SO}_{4}^{2-}$ controls. This is because of similarities in $\mathrm{pH}$ and $\varepsilon\left(\mathrm{NO}_{3}^{-}\right)$between these sites. For the haze condition in Beijing, $\mathrm{NH}_{x}$ control does not produce as much $\mathrm{PM}_{2.5}$ ion mass reduction as $\mathrm{NO}_{3}^{\mathrm{T}}$ and $\mathrm{SO}_{4}^{2-}$ controls, unless more than a $60 \%$ reduction in $\mathrm{NH}_{x}$ is reached. However, after that PM mass reduction is fast. At $90 \% \mathrm{NH}_{x}$ reduction, a decrease of more than half of the particle ionic mass is predicted. $\mathrm{NO}_{3}^{\mathrm{T}}$ and $\mathrm{SO}_{4}^{2-}$ controls produce equivalent results due to the same mass fractions of $\mathrm{NO}_{3}^{-}$and $\mathrm{SO}_{4}^{2-}$ (both equal to $36 \%$ ) and linear response in particle ionic mass. Comparing the $\mathrm{pH}$ profiles, the largest reduction in $\mathrm{pH}$ is predicted for Beijing haze if reducing $\mathrm{NH}_{x}$. At $50 \% \mathrm{NH}_{x}$ reduction, $\mathrm{pH}$ changes from 4.1 to 2.5 in Beijing, whereas pH only changes from 3.9 to 3.3 in Cabauw. This can be explained by differences in $\varepsilon\left(\mathrm{NH}_{4}^{+}\right)$, which are at $60 \%$ in Beijing versus $27 \%$ in Cabauw.

\subsection{Other implications of lowering $\mathrm{pH}$ by $\mathrm{NH}_{3}$ emission control}

The benefit of reducing $\mathrm{NH}_{3}$ emission to reduce ambient $\mathrm{PM}_{2.5}$ mass concentrations depends on the conditions at a specific site. While particle $\mathrm{pH}$ is lowered during the process, other $\mathrm{pH}$-related atmospheric processes are affected. One potentially unintended effect is nitrogen deposition. Nitrogen dry deposition rates depend on particle versus gasphase fractions since there are large differences between gas and particle deposition velocities. For example, the dry deposition velocity of $\mathrm{NH}_{3}$ is about $1-2 \mathrm{~cm} \mathrm{~s}^{-1}$ over forest, agricultural, or mixed-use land and 10 times that of $\mathrm{NH}_{4}^{+}$ (Duyzer, 1994; Schrader and Brummer, 2014). Also, the dry deposition velocity of $\mathrm{HNO}_{3}$ is similar to that of $\mathrm{NH}_{3}$ (Huebert and Robert, 1985). Lowering particle $\mathrm{pH}$ through $\mathrm{NH}_{3}$ reductions will decrease overall reduced nitrogen deposition, but may result in more localized oxidized nitrogen dry deposition, if the lower $\mathrm{pH}$ results in $\mathrm{NO}_{3}^{-}$evaporation and higher $\mathrm{HNO}_{3}$ concentrations. Deposition due to wet removal processes is not considered here.

An additional consequence of lowering particle $\mathrm{pH}$ is that it can increase aerosol toxicity. Many studies have identified links between strong particle acidity and adverse health endpoints (Koutrakis et al., 1988; Thurston et al., 1994; Raizenne et al., 1996; Gwynn et al., 2000; Lelieveld et al., 2015). We recently showed one way this can happen is due to increased conversion of $\mathrm{PM}_{2.5}$ insoluble transition metals to soluble forms by strong acidity (Fang et al., 2017), which increases the particles' ability to induce oxidative stress (Ghio et al., 2012). Lowering $\mathrm{pH}$ may reduce $\mathrm{PM}_{2.5}$ mass but increase the overall potential for adverse health effects due to significantly greater toxicity of soluble metals relative to ammonium nitrate. Finally, lowering $\mathrm{pH}$ can also impact the deposition pattern and bioavailability of trace-limiting nutrients such as $\mathrm{Fe}, \mathrm{P}$, and other metals (Meskhidze et al., 2003; Nenes et al., 2011) with important implications for primary 
productivity (Meskhidze et al., 2005) and even the oxygen state of the subsurface ocean (Ito et al., 2016).

\section{Summary}

In this study, we assess the effectiveness of $\mathrm{NH}_{3}$ control as a way to lower inorganic $\mathrm{PM}_{2.5}$ mass based on observational data sets from the US, the Netherlands, and China during different seasons. These sites encompass a diverse range in (i) $\mathrm{NH}_{3}$ and inorganic aerosol concentrations and (ii) thermodynamic conditions. In all cases, the relative humidities are sufficiently high (average $\mathrm{RH}>55 \%$ ) that a completely deliquesced inorganic phase is a reasonable assumption, which is implicit to the thermodynamic calculations (metastable mode). Focusing on Cabauw, the Netherlands, a site in a region highly impacted by agricultural emissions, we show that the effectiveness of $\mathrm{NH}_{3}$ control changes with season. In winter, a much larger reduction in $\mathrm{NH}_{3}$ is required to reduce $\mathrm{NO}_{3}^{-}$than in summer, making $\mathrm{NO}_{x}$ control more effective in winter. This is explained by a shift in the $\mathrm{HNO}_{3}-$ $\mathrm{NO}_{3}^{-}$partitioning $\left(\varepsilon\left(\mathrm{NO}_{3}^{-}\right)\right)$curve to lower $\mathrm{pH}$ in winter and $\mathrm{pH}_{50}$ (where $\varepsilon\left(\mathrm{NO}_{3}^{-}\right)=50 \%$ ) further from the actual ambient particle $\mathrm{pH}$. A similar situation is seen in Beijing in winter, where $\mathrm{NH}_{3}$ emission control would also be less effective. In most other sites investigated, $\mathrm{NH}_{3}$ control is effective in reducing $\mathrm{PM}_{2.5}$ mass in regions with reasonably high ammonium nitrate concentrations.

The analysis presented here provides a conceptual and direct evaluation of how the inorganic gas-particle system can be expected to respond to changes in $\mathrm{NH}_{3}$ emissions and how it contrasts to $\mathrm{NO}_{x}$ control. The approach relies on the single $\mathrm{HNO}_{3}-\mathrm{NO}_{3}^{-}$partitioning equation and the use of a thermodynamic model to predict $\mathrm{pH}$. Other approaches are also often used to address this question. Chemical transport models with imbedded thermodynamic sub-modules (such as ISORROPIA) can provide a more detailed analysis that includes other possible impacts of the emission controls, such as ammonia and nitrate deposition and associated environmental impacts. However, the various uncertainties associated with the many simulated processes involved in these models (e.g., emissions and processing) can affect the predicted results and obscure the fundamental partitioning processes. With the more transparent and accessible approach presented here, this is less of an issue. Both approaches have benefits, but, regardless of which analysis is utilized, it is always useful to explicitly report estimated particle $\mathrm{pH}$ as it allows assessment of the predictions and provides contrasts between studies at specific sites.

Data availability. The Cabauw MARGA data can be accessed by request to Rene Otjes (ECN). The meteorological data can be accessed at the CESAR database (http://www.cesar-database.nl/; last access: 4 February 2017). Alternatively, the model input data files can be obtained by request (rweber@eas.gatech.edu). The campaign average parameters for plotting Figs. 1-5 can be found in Table S1 in the Supplement.

Supplement. The supplement related to this article is available online at: https://doi.org/10.5194/acp-18-12241-2018-supplement.

Author contributions. RO, PS, and ASK collected the data. HG analyzed the data. HG, AN, and RJW were involved in data interpretation and wrote the paper.

Competing interests. The authors declare that they have no conflict of interest.

Acknowledgements. This work was supported by the National Science Foundation (NSF) under grant AGS-1360730 and by the US Environmental Protection Agency STAR grant R835882. This publication's contents are solely the responsibility of the grantee and do not necessarily represent the official views of the US EPA. Further, the US EPA does not endorse the purchase of any commercial products or services mentioned in the publication. Athanasios Nenes acknowledges support from the European Research Council Project PyroTRACH (Pyrogenic TRansformations Affecting Climate and Health) grant agreement 726165. We acknowledge Fred Bosveld (KNMI) and the CESAR database for sharing the meteorological data.

Edited by: Qiang Zhang

Reviewed by: two anonymous referees

\section{References}

An, W. J., Pathak, R. K., Lee, B.-H., and Pandis, S. N.: Aerosol volatility measurement using an improved thermodenuder: Application to secondary organic aerosol, J. Aerosol Sci., 38, 305314, https://doi.org/10.1016/j.jaerosci.2006.12.002, 2007.

Aneja, V. P., Schlesinger, W. H., and Erisman, J. W.: Effects of Agriculture upon the Air Quality and Climate: Research, Policy, and Regulations, Environ. Sci. Technol., 43, 4234-4240, https://doi.org/10.1021/es8024403, 2009.

Atkinson, R.: Atmospheric chemistry of VOCs and $\mathrm{NO}_{x}$, Atmos. Environ., 34, 2063-2101, https://doi.org/10.1016/s13522310(99)00460-4, 2000.

Bauer, S. E., Tsigaridis, K., and Miller, R.: Significant atmospheric aerosol pollution caused by world food cultivation, Geophys. Res. Lett., 43, 5394-5400, https://doi.org/10.1002/2016gl068354, 2016.

Behera, S. N., Sharma, M., Aneja, V. P., and Balasubramanian, R.: Ammonia in the atmosphere: a review on emission sources, atmospheric chemistry and deposition on terrestrial bodies, Environ. Sci. Pollut. Res. Int., 20, 8092-8131, https://doi.org/10.1007/s11356-013-2051-9, 2013. 
Bellouin, N., Rae, J., Jones, A., Johnson, C., Haywood, J., and Boucher, O.: Aerosol forcing in the Climate Model Intercomparison Project (CMIP5) simulations by HadGEM2-ES and the role of ammonium nitrate, J. Geophys. Res., 116, D20206, https://doi.org/10.1029/2011jd016074, 2011.

Bertram, A. K., Martin, S. T., Hanna, S. J., Smith, M. L., Bodsworth, A., Chen, Q., Kuwata, M., Liu, A., You, Y., and Zorn, S. R.: Predicting the relative humidities of liquid-liquid phase separation, efflorescence, and deliquescence of mixed particles of ammonium sulfate, organic material, and water using the organic-to-sulfate mass ratio of the particle and the oxygen-tocarbon elemental ratio of the organic component, Atmos. Chem. Phys., 11, 10995-11006, https://doi.org/10.5194/acp-11-109952011, 2011.

Camargo, J. A. and Alonso, A.: Ecological and toxicological effects of inorganic nitrogen pollution in aquatic ecosystems: A global assessment, Environ. Int., 32, 831-849, https://doi.org/10.1016/j.envint.2006.05.002, 2006.

Cheng, Y., Zheng, G., Wei, C., Mu, Q., Zheng, B., Wang, Z., Gao, M., Zhang, Q., He, K., Carmichael, G., Poschl, U., and Su, H.: Reactive nitrogen chemistry in aerosol water as a source of sulfate during haze events in China, Sci. Adv., 2, e1601530, https://doi.org/10.1126/sciadv.1601530, 2016.

Cohen, A. J., Brauer, M., Burnett, R., Anderson, H. R., Frostad, J., Estep, K., Balakrishnan, K., Brunekreef, B., Dandona, L., Dandona, R., Feigin, V., Freedman, G., Hubbell, B., Jobling, A., Kan, H., Knibbs, L., Liu, Y., Martin, R., Morawska, L., Pope, C. A., Shin, H., Straif, K., Shaddick, G., Thomas, M., van Dingenen, R., van Donkelaar, A., Vos, T., Murray, C. J. L., and Forouzanfar, M. H.: Estimates and 25-year trends of the global burden of disease attributable to ambient air pollution: an analysis of data from the Global Burden of Diseases Study 2015, Lancet, 389, 1907-1918, https://doi.org/10.1016/s0140-6736(17)30505-6, 2017.

Cruz, C. N., Dassios, K. G., and Pandis, S. N.: The effect of dioctyl phthalate films on the ammonium nitrate aerosol evaporation rate, Atmos. Environ., 34, 3897-3905, https://doi.org/10.1016/S1352-2310(00)00173-4, 2000.

Dassios, K. G. and Pandis, S. N.: The mass accommodation coefficient of ammonium nitrate aerosol, Atmos. Environ., 33, 2993 3003, https://doi.org/10.1016/S1352-2310(99)00079-5, 1999.

Duyzer, J.: Dry deposition of ammonia and ammonium aerosols over heathland, J. Geophys. Res., 99, 18757-18763, https://doi.org/10.1029/94jd01210, 1994.

Eddingsaas, N. C., VanderVelde, D. G., and Wennberg, P. O.: Kinetics and Products of the Acid-Catalyzed Ring-Opening of Atmospherically Relevant Butyl Epoxy Alcohols, J. Phys. Chem. A, 114, 8106-8113, https://doi.org/10.1021/Jp103907c, 2010.

Edwards, P. M., Aikin, K. C., Dube, W. P., Fry, J. L., Gilman, J. B., de Gouw, J. A., Graus, M. G., Hanisco, T. F., Holloway, J., Hübler, G., Kaiser, J., Keutsch, F. N., Lerner, B. M., Neuman, J. A., Parrish, D. D., Peischl, J., Pollack, I. B., Ravishankara, A. R., Roberts, J. M., Ryerson, T. B., Trainer, M., Veres, P. R., Wolfe, G. M., Warneke, C., and Brown, S. S.: Transition from high- to low$\mathrm{NO}_{x}$ control of night-time oxidation in the southeastern US, Nat. Geosci., 10, 490-495, https://doi.org/10.1038/ngeo2976, 2017.

Erisman, J. W. and Schaap, M.: The need for ammonia abatement with respect to secondary PM reductions in Europe, Environ. Pollut., 129, 159-163, https://doi.org/10.1016/j.envpol.2003.08.042, 2004.
Erisman, J. W., Sutton, M. A., Galloway, J., Klimont, Z., and Winiwarter, W.: How a century of ammonia synthesis changed the world, Nat. Geosci., 1, 636-639, 2008.

Fang, T., Guo, H., Zeng, L., Verma, V., Nenes, A., and Weber, R. J.: Highly Acidic Ambient Particles, Soluble Metals, and Oxidative Potential: A Link between Sulfate and Aerosol Toxicity, Environ. Sci. Technol., 51, 2611-2620, https://doi.org/10.1021/acs.est.6b06151, 2017.

Farmer, D. K., Matsunaga, A., Docherty, K. S., Surratt, J. D., Seinfeld, J. H., Ziemann, P. J., and Jimenez, J. L.: Response of an aerosol mass spectrometer to organonitrates and organosulfates and implications for atmospheric chemistry, P. Natl. Acad. Sci. USA, 107, 6670-6675, https://doi.org/10.1073/pnas.0912340107, 2010.

Fountoukis, C. and Nenes, A.: ISORROPIA II: a computationally efficient thermodynamic equilibrium model for $\mathrm{K}^{+}$. $\mathrm{Ca}^{2+}-\mathrm{Mg}^{2+}-\mathrm{NH}_{4}^{+}-\mathrm{Na}^{+}-\mathrm{SO}_{4}^{2-}-\mathrm{NO}_{3}^{-}-\mathrm{Cl}^{-}-\mathrm{H}_{2} \mathrm{O}$ aerosols, Atmos. Chem. Phys., 7, 4639-4659, https://doi.org/10.5194/acp-74639-2007, 2007.

Fountoukis, C., Nenes, A., Sullivan, A., Weber, R., Van Reken, T., Fischer, M., Matías, E., Moya, M., Farmer, D., and Cohen, R. C.: Thermodynamic characterization of Mexico City aerosol during MILAGRO 2006, Atmos. Chem. Phys., 9, 2141-2156, https://doi.org/10.5194/acp-9-2141-2009, 2009.

Fowler, D., Coyle, M., Skiba, U., Sutton, M. A., Cape, J. N., Reis, S., Sheppard, L. J., Jenkins, A., Grizzetti, B., Galloway, J. N., Vitousek, P., Leach, A., Bouwman, A. F., Butterbach-Bahl, K., Dentener, F., Stevenson, D., Amann, M., and Voss, M.: The global nitrogen cycle in the twenty-first century, Philos. T. R. Soc. B, 368, 20130164, https://doi.org/10.1098/rstb.2013.0164, 2013.

Fridlind, A. M. and Jacobson, M. Z.: A study of gas-aerosol equilibrium and aerosol $\mathrm{pH}$ in the remote marine boundary layer during the First Aerosol Characterization Experiment (ACE 1), J. Geophys. Res., 105, 17325-17340, https://doi.org/10.1029/2000jd900209, 2000.

Galloway, J. N., Aber, J. D., Erisman, J. W., Seitzinger, S. P., Howarth, R. W., Cowling, E. B., and Cosby, B. J.: The Nitrogen Cascade, BioScience, 53, 341-35, https://doi.org/10.1641/00063568(2003)053[0341:Tnc]2.0.Co;2, 2003.

Gerland, P., Raftery, A. E., Sevcikova, H., Li, N., Gu, D., Spoorenberg, T., Alkema, L., Fosdick, B. K., Chunn, J., Lalic, N., Bay, G., Buettner, T., Heilig, G. K., and Wilmoth, J.: World population stabilization unlikely this century, Science, 346, 234-237, https://doi.org/10.1126/science.1257469, 2014.

Ghio, A. J., Carraway, M. S., and Madden, M. C.: Composition of air pollution particles and oxidative stress in cells, tissues, and living systems, J. Toxicol. Env. Heal. B, 15, 1-21, https://doi.org/10.1080/10937404.2012.632359, 2012.

Guo, H., Xu, L., Bougiatioti, A., Cerully, K. M., Capps, S. L., Hite Jr., J. R., Carlton, A. G., Lee, S.-H., Bergin, M. H., Ng, N. L., Nenes, A., and Weber, R. J.: Fine-particle water and $\mathrm{pH}$ in the southeastern United States, Atmos. Chem. Phys., 15, 5211-5228, https://doi.org/10.5194/acp-15-5211-2015, 2015.

Guo, H., Sullivan, A. P., Campuzano-Jost, P., Schroder, J. C., LopezHilfiker, F. D., Dibb, J. E., Jimenez, J. L., Thornton, J. A., Brown, S. S., Nenes, A., and Weber, R. J.: Fine particle pH and the partitioning of nitric acid during winter in the north- 
eastern United States, J. Geophys. Res., 121, 10355-10376, https://doi.org/10.1002/2016jd025311, 2016.

Guo, H., Liu, J., Froyd, K. D., Roberts, J. M., Veres, P. R., Hayes, P. L., Jimenez, J. L., Nenes, A., and Weber, R. J.: Fine particle $\mathrm{pH}$ and gas-particle phase partitioning of inorganic species in Pasadena, California, during the 2010 CalNex campaign, Atmos. Chem. Phys., 17, 5703-5719, https://doi.org/10.5194/acp17-5703-2017, 2017a.

Guo, H., Nenes, A., and Weber, R. J.: The underappreciated role of nonvolatile cations on aerosol ammonium-sulfate molar ratios, Atmos. Chem. Phys. Discuss., https://doi.org/10.5194/acp-2017737, in review, $2017 \mathrm{~b}$.

Guo, H., Weber, R. J., and Nenes, A.: High levels of ammonia do not raise fine particle $\mathrm{pH}$ sufficiently to yield nitrogen oxide-dominated sulfate production, Sci. Rep., 7, 12109, https://doi.org/10.1038/s41598-017-11704-0, 2017c.

Gwynn, R. C., Burnett, R. T., and Thurston, G. D.: A time-series analysis of acidic particulate matter and daily mortality and morbidity in the Buffalo, New York, region, Environ. Health Persp., 108, 125-133, https://doi.org/10.2307/3454510, 2000.

Hand, J. L., Schichtel, B. A., Malm, W. C., and Pitchford, M. L.: Particulate sulfate ion concentration and $\mathrm{SO}_{2}$ emission trends in the United States from the early 1990s through 2010, Atmos. Chem. Phys., 12, 10353-10365, https://doi.org/10.5194/acp-1210353-2012, 2012.

Haywood, J., and Boucher, O.: Estimates of the direct and indirect radiative forcing due to tropospheric aerosols: A review, Rev. Geophys., 38, 513-543, https://doi.org/10.1029/1999rg000078, 2000.

Hennigan, C. J., Izumi, J., Sullivan, A. P., Weber, R. J., and Nenes, A.: A critical evaluation of proxy methods used to estimate the acidity of atmospheric particles, Atmos. Chem. Phys., 15, 27752790, https://doi.org/10.5194/acp-15-2775-2015, 2015.

Hidy, G. M., Blanchard, C. L., Baumann, K., Edgerton, E., Tanenbaum, S., Shaw, S., Knipping, E., Tombach, I., Jansen, J., and Walters, J.: Chemical climatology of the southeastern United States, 1999-2013, Atmos. Chem. Phys., 14, 11893-11914, https://doi.org/10.5194/acp-14-11893-2014, 2014.

Huebert, B. J. and Robert, C. H.: The Dry Deposition of Nitric-Acid to Grass, J. Geophys. Res., 90, 2085-2090, https://doi.org/10.1029/JD090iD01p02085, 1985.

IPCC: Climate Change 2013: The Physical Science Basis. Contribution of Working Group I to the Fifth Assessment Report of the Intergovernmental Panel on Climate Change, Cambridge, United Kingdom and New York, NY, USA, 1535, 2013.

Ito, T., Nenes, A., Johnson, M. S., Meskhidze, N., and Deutsch, C.: Acceleration of oxygen decline in the tropical Pacific over the past decades by aerosol pollutants, Nat. Geosci., 9, 443-447, https://doi.org/10.1038/ngeo2717, 2016.

Jang, M., Czoschke, N. M., Lee, S., and Kamens, R. M.: Heterogeneous atmospheric aerosol production by acidcatalyzed particle-phase reactions, Science, 298, 814-817, https://doi.org/10.1126/science.1075798, 2002.

Kanakidou, M., Seinfeld, J. H., Pandis, S. N., Barnes, I., Dentener, F. J., Facchini, M. C., Van Dingenen, R., Ervens, B., Nenes, A., Nielsen, C. J., Swietlicki, E., Putaud, J. P., Balkanski, Y., Fuzzi, S., Horth, J., Moortgat, G. K., Winterhalter, R., Myhre, C. E. L., Tsigaridis, K., Vignati, E., Stephanou, E. G., and Wilson, J.: Organic aerosol and global climate modelling: a review, Atmos.
Chem. Phys., 5, 1053-1123, https://doi.org/10.5194/acp-5-10532005, 2005.

Kiendler-Scharr, A., Mensah, A. A., Friese, E., et al.: Ubiquity of organic nitrates from nighttime chemistry in the European submicron aerosol, Geophys. Res. Lett., 43, 7735-7744, https://doi.org/10.1002/2016gl069239, 2016.

Koutrakis, P., Wolfson, J. M., and Spengler, J. D.: An improved method for measuring aerosol strong acidity: Results from a nine-month study in St Louis, Missouri and Kingston, Tennessee, Atmos. Environ., 22, 157-162, https://doi.org/10.1016/00046981(88)90308-3, 1988.

Krupa, S. V.: Effects of atmospheric ammonia $\left(\mathrm{NH}_{3}\right)$ on terrestrial vegetation: a review, Environ. Pollut., 124, 179-221, https://doi.org/10.1016/s0269-7491(02)00434-7, 2003.

Lelieveld, J., Evans, J. S., Fnais, M., Giannadaki, D., and Pozzer, A.: The contribution of outdoor air pollution sources to premature mortality on a global scale, Nature, 525, 367-371, https://doi.org/10.1038/nature15371, 2015.

Lim, S. S., Vos, T., Flaxman, A. D., et al.: A comparative risk assessment of burden of disease and injury attributable to 67 risk factors and risk factor clusters in 21 regions, 1990-2010: a systematic analysis for the Global Burden of Disease Study 2010, Lancet, 380, 2224-2260, https://doi.org/10.1016/S0140-6736(12)61766$8,2012$.

Lolkema, D. E., Noordijk, H., Stolk, A. P., Hoogerbrugge, R., van Zanten, M. C., and van Pul, W. A. J.: The Measuring Ammonia in Nature (MAN) network in the Netherlands, Biogeosciences, 12, 5133-5142, https://doi.org/10.5194/bg-12-5133-2015, 2015.

Longo, A. F., Feng, Y., Lai, B., Landing, W. M., Shelley, R. U., Nenes, A., Mihalopoulos, N., Violaki, K., and Ingall, E. D.: Influence of Atmospheric Processes on the Solubility and Composition of Iron in Saharan Dust, Environ. Sci. Technol., 50, 6912 6920, https://doi.org/10.1021/acs.est.6b02605, 2016.

Meskhidze, N., Chameides, W. L., Nenes, A., and Chen, G.: Iron mobilization in mineral dust: Can anthropogenic $\mathrm{SO}_{2}$ emissions affect ocean productivity?, Geophys. Res. Lett., 30, 2085, https://doi.org/10.1029/2003gl018035, 2003.

Meskhidze, N., Chameides, W. L., and Nenes, A.: Dust and pollution: A recipe for enhanced ocean fertilization?, J. Geophys. Res., 110, D03301, https://doi.org/10.1029/2004jd005082, 2005.

Nah, T., Guo, H., Sullivan, A. P., Chen, Y., Tanner, D. J., Nenes, A., Russell, A., Ng, N. L., Huey, L. G., and Weber, R. J.: Characterization of Aerosol Composition, Aerosol Acidity and Organic Acid Partitioning at an Agriculture-Intensive Rural Southeastern U.S. Site, Atmos. Chem. Phys. Discuss., https://doi.org/10.5194/acp-2018-373, in review, 2018.

Nenes, A., Krom, M. D., Mihalopoulos, N., Van Cappellen, P., Shi, Z., Bougiatioti, A., Zarmpas, P., and Herut, B.: Atmospheric acidification of mineral aerosols: a source of bioavailable phosphorus for the oceans, Atmos. Chem. Phys., 11, 6265-6272, https://doi.org/10.5194/acp-11-6265-2011, 2011.

Paulot, F. and Jacob, D. J.: Hidden cost of U.S. agricultural exports: particulate matter from ammonia emissions, Environ. Sci. Technol., 48, 903-908, https://doi.org/10.1021/es4034793, 2014.

Paulot, F., Fan, S., and Horowitz, L. W.: Contrasting seasonal responses of sulfate aerosols to declining $\mathrm{SO}_{2}$ emissions in the Eastern U.S.: Implications for the efficacy of $\mathrm{SO}_{2}$ emission controls, Geophys. Res. Lett., 44, 455-464, https://doi.org/10.1002/2016gl070695, 2017. 
Perring, A. E., Pusede, S. E., and Cohen, R. C.: An observational perspective on the atmospheric impacts of alkyl and multifunctional nitrates on ozone and secondary organic aerosol, Chem. Rev., 113, 5848-5870, https://doi.org/10.1021/cr300520x, 2013.

Perrino, C., Catrambone, M., Di Menno Di Bucchianico, A., and Allegrini, I.: Gaseous ammonia in the urban area of Rome, Italy and its relationship with traffic emissions, Atmos. Environ., 36, 5385-5394, https://doi.org/10.1016/s1352-2310(02)004697, 2002.

Pinder, R. W., Adams, P. J., and Pandis, S. N.: Ammonia Emission Controls as a Cost-Effective Strategy for Reducing Atmospheric Particulate Matter in the Eastern United States, Environ. Sci. Technol., 41, 380-386, https://doi.org/10.1021/es060379a, 2007.

Pinder, R. W., Gilliland, A. B., and Dennis, R. L.: Environmental impact of atmospheric $\mathrm{NH}_{3}$ emissions under present and future conditions in the eastern United States, Geophys. Res. Lett., 35, L12808, https://doi.org/10.1029/2008g1033732, 2008.

Pope, C. A., III, Burnett, R. T., Thurston, G. D., Thun, M. J., Calle, E. E., Krewski, D., and Godleski, J. J.: Cardiovascular mortality and long-term exposure to particulate air pollution: epidemiological evidence of general pathophysiological pathways of disease, Circulation, 109, 71-77, https://doi.org/10.1161/01.CIR.0000108927.80044.7F, 2004.

Pozzer, A., Tsimpidi, A. P., Karydis, V. A., de Meij, A., and Lelieveld, J.: Impact of agricultural emission reductions on fine-particulate matter and public health, Atmos. Chem. Phys., 17, 12813-12826, https://doi.org/10.5194/acp-17-12813-2017, 2017.

Pye, H. O. T., Zuend, A., Fry, J. L., Isaacman-VanWertz, G., Capps, S. L., Appel, K. W., Foroutan, H., Xu, L., Ng, N. L., and Goldstein, A. H.: Coupling of organic and inorganic aerosol systems and the effect on gas-particle partitioning in the southeastern US, Atmos. Chem. Phys., 18, 357-370, https://doi.org/10.5194/acp18-357-2018, 2018.

Raizenne, M., Neas, L. M., Damokosh, A. I., Dockery, D. W., Spengler, J. D., Koutrakis, P., Ware, J. H., and Speizer, F. E.: Health effects of acid aerosols on North American children: pulmonary function, Environ. Health Persp., 104, 506-514, https://doi.org/10.2307/3432991, 1996.

Rumsey, I. C., Cowen, K. A., Walker, J. T., Kelly, T. J., Hanft, E. A., Mishoe, K., Rogers, C., Proost, R., Beachley, G. M., Lear, G., Frelink, T., and Otjes, R. P.: An assessment of the performance of the Monitor for AeRosols and GAses in ambient air (MARGA): a semi-continuous method for soluble compounds, Atmos. Chem. Phys., 14, 5639-5658, https://doi.org/10.5194/acp-145639-2014, 2014.

Russell, A. R., Valin, L. C., and Cohen, R. C.: Trends in OMI $\mathrm{NO}_{2}$ observations over the United States: effects of emission control technology and the economic recession, Atmos. Chem. Phys., 12, 12197-12209, https://doi.org/10.5194/acp-12-121972012, 2012.

Sardar, S. B., Fine, P. M., and Sioutas, C.: Seasonal and spatial variability of the size-resolved chemical composition of particulate matter $\left(\mathrm{PM}_{10}\right)$ in the Los Angeles Basin, J. Geophys. Res., 110, D07S08, https://doi.org/10.1029/2004jd004627, 2005.

Schaap, M., Otjes, R. P., and Weijers, E. P.: Illustrating the benefit of using hourly monitoring data on secondary inorganic aerosol and its precursors for model evaluation, Atmos. Chem.
Phys., 11, 11041-11053, https://doi.org/10.5194/acp-11-110412011, 2011.

Schlag, P., Kiendler-Scharr, A., Blom, M. J., Canonaco, F., Henzing, J. S., Moerman, M., Prévôt, A. S. H., and Holzinger, R.: Aerosol source apportionment from 1-year measurements at the CESAR tower in Cabauw, the Netherlands, Atmos. Chem. Phys., 16, 8831-8847, https://doi.org/10.5194/acp-16-8831-2016, 2016.

Schlag, P., Rubach, F., Mentel, T. F., Reimer, D., Canonaco, F., Henzing, J. S., Moerman, M., Otjes, R., Prevot, A. S. H., Rohrer, F., Rosati, B., Tillmann, R., Weingartner, E., and Kiendler-Scharr, A.: Ambient and laboratory observations of organic ammonium salts in $\mathrm{PM}_{1}$, Faraday Discuss., 200, 331-351, https://doi.org/10.1039/c7fd00027h, 2017.

Schrader, F. and Brummer, C.: Land Use Specific Ammonia Deposition Velocities: a Review of Recent Studies (2004-2013), Water Air Soil Pollut., 225, 2114, https://doi.org/10.1007/s11270-0142114-7, 2014.

Shah, V., Jaeglé, L., Thornton, J. A., Lopez-Hilfiker, F. D., Lee, B. H., Schroder, J. C., Campuzano-Jost, P., Jimenez, J. L., Guo, H., Sullivan, A. P., Weber, R. J., Green, J. R., Fiddler, M. N., Bililign, S., Campos, T. L., Stell, M., Weinheimer, A. J., Montzka, D. D., and Brown, S. S.: Chemical feedbacks weaken the wintertime response of particulate sulfate and nitrate to emissions reductions over the eastern United States, P. Natl. Acad. Sci. USA, https://doi.org/10.1073/pnas.1803295115, 2018.

Skjøth, C. A. and Geels, C.: The effect of climate and climate change on ammonia emissions in Europe, Atmos. Chem. Phys., 13, 117-128, https://doi.org/10.5194/acp-13-117-2013, 2013.

Song, S., Gao, M., Xu, W., Shao, J., Shi, G., Wang, S., Wang, Y., Sun, Y., and McElroy, M. B.: Fine-particle $\mathrm{pH}$ for Beijing winter haze as inferred from different thermodynamic equilibrium models, Atmos. Chem. Phys., 18, 7423-7438, https://doi.org/10.5194/acp-18-7423-2018, 2018.

Stockdale, A., Krom, M. D., Mortimer, R. J., Benning, L. G., Carslaw, K. S., Herbert, R. J., Shi, Z., Myriokefalitakis, S., Kanakidou, M., and Nenes, A.: Understanding the nature of atmospheric acid processing of mineral dusts in supplying bioavailable phosphorus to the oceans, P. Natl. Acad. Sci. USA, 113, 14639-14644, https://doi.org/10.1073/pnas.1608136113, 2016.

Surratt, J. D., Chan, A. W., Eddingsaas, N. C., Chan, M., Loza, C. L., Kwan, A. J., Hersey, S. P., Flagan, R. C., Wennberg, P. O., and Seinfeld, J. H.: Reactive intermediates revealed in secondary organic aerosol formation from isoprene, P. Natl. Acad. Sci. USA, 107, 6640-6645, https://doi.org/10.1073/pnas.0911114107, 2010.

Thurston, G. D., Ito, K., Hayes, C. G., Bates, D. V., and Lippmann, M.: Respiratory hospital admissions and summertime haze air pollution in Toronto, Ontario: consideration of the role of acid aerosols, Environ. Res., 65, 271-290, https://doi.org/10.1006/enrs.1994.1037, 1994.

Tsimpidi, A. P., Karydis, V. A., and Pandis, S. N.: Response of Inorganic Fine Particulate Matter to Emission Changes of Sulfur Dioxide and Ammonia: The Eastern United States as a Case Study, J. Air Waste Ma., 57, 1489-1498, https://doi.org/10.3155/1047-3289.57.12.1489, 2007.

Vasilakos, P., Russell, A., Weber, R., and Nenes, A.: Understanding nitrate formation in a world with less sulfate, Atmos. Chem. 
Phys. Discuss., https://doi.org/10.5194/acp-2018-406, in review, 2018.

Wang, G., Zhang, R., Gomez, M. E., et al.: Persistent sulfate formation from London Fog to Chinese haze, P. Natl. Acad. Sci. USA, 113, 13630-13635, https://doi.org/10.1073/pnas.1616540113, 2016.

Wang, S., Xing, J., Jang, C., Zhu, Y., Fu, J. S., and Hao, J.: Impact assessment of ammonia emissions on inorganic aerosols in East China using response surface modeling technique, Environ. Sci. Technol., 45, 9293-9300, https://doi.org/10.1021/es2022347, 2011.

Warner, J. X., Wei, Z., Strow, L. L., Dickerson, R. R., and Nowak, J. B.: The global tropospheric ammonia distribution as seen in the 13-year AIRS measurement record, Atmos. Chem. Phys., 16, 5467-5479, https://doi.org/10.5194/acp-16-5467-2016, 2016.

Warner, J. X., Dickerson, R. R., Wei, Z., Strow, L. L., Wang, Y., and Liang, Q.: Increased atmospheric ammonia over the world's major agricultural areas detected from space, Geophys. Res. Lett., 44, 2875-2884, https://doi.org/10.1002/2016g1072305, 2017.

Weber, R. J., Guo, H., Russell, A. G., and Nenes, A.: High aerosol acidity despite declining atmospheric sulfate concentrations over the past 15 years, Nat. Geosci., 9, 282-285, https://doi.org/10.1038/ngeo2665, 2016.

Wells, M., Choularton, T. W., and Bower, K. N.: A modelling study of the interaction of ammonia with cloud, Atmos. Environ., 32, 359-363, https://doi.org/10.1016/s1352-2310(97)00199-4, 1998.

Xu, L., Suresh, S., Guo, H., Weber, R. J., and Ng, N. L.: Aerosol characterization over the southeastern United States using high-resolution aerosol mass spectrometry: spatial and seasonal variation of aerosol composition and sources with a focus on organic nitrates, Atmos. Chem. Phys., 15, 7307-7336, https://doi.org/10.5194/acp-15-7307-2015, 2015.
Yamamoto, N., Kabeya, N., Onodera, M., Takahahi, S., Komori, Y., Nakazuka, E., and Shirai, T.: Seasonal variation of atmospheric ammonia and particulate ammonium concentrations in the urban atmosphere of yokohama over a 5-year period, Atmos. Environ., 22, 2621-2623, https://doi.org/10.1016/0004-6981(88)90498-2, 1988.

Young, A. H., Keene, W. C., Pszenny, A. A. P., Sander, R., Thornton, J. A., Riedel, T. P., and Maben, J. R.: Phase partitioning of soluble trace gases with size-resolved aerosols in near-surface continental air over northern Colorado, USA, during winter, J. Geophys. Res., 118, 9414-9427, https://doi.org/10.1002/jgrd.50655, 2013.

Zhang, L., Chen, Y., Zhao, Y., Henze, D. K., Zhu, L., Song, Y., Paulot, F., Liu, X., Pan, Y., Lin, Y., and Huang, B.: Agricultural ammonia emissions in China: reconciling bottom-up and top-down estimates, Atmos. Chem. Phys., 18, 339-355, https://doi.org/10.5194/acp-18-339-2018, 2018.

Zhang, Q., Jimenez, J. L., Canagaratna, M. R., et al.: Ubiquity and dominance of oxygenated species in organic aerosols in anthropogenically-influenced Northern Hemisphere midlatitudes, Geophys. Res. Lett., 34, L13801, https://doi.org/10.1029/2007gl029979, 2007.

Zhu, S., Sartelet, K., Zhang, Y., and Nenes, A.: Threedimensional modeling of the mixing state of particles over Greater Paris, J. Geophys. Res., 121, 5930-5947, https://doi.org/10.1002/2015jd024241, 2016.

Zhu, S., Horne, J. R., Montoya-Aguilera, J., Hinks, M. L., Nizkorodov, S. A., and Dabdub, D.: Modeling reactive ammonia uptake by secondary organic aerosol in CMAQ: application to the continental US, Atmos. Chem. Phys., 18, 3641-3657, https://doi.org/10.5194/acp-18-3641-2018, 2018. 